\title{
Update on the genetics of spastic paraplegias
}

Maxime Boutry ${ }^{1,2 *}$, Sara Morais ${ }^{1,2,3}$, Giovanni Stevanin ${ }^{1,2}$

1 Institut du Cerveau et de la Moelle épinière, Sorbonne Université UMR_S1127, INSERM Unit 1127, CNRS UMR7225, 75013, Paris, France

2 Ecole Pratique des Hautes Etudes (EPHE), Paris Sciences Lettres (PSL) Research University, Neurogenetics team, 75013, Paris, France

3 UnIGENe, Instituto de Investigação e Inovação em Saúde, Universidade do Porto, Porto, Portugal

*Current affiliation: Cell Biology Program, Hospital for Sick Children, Toronto, Ontario, Canada

\section{Corresponding author:}

Giovanni Stevanin

giovanni.stevanin@upmc.fr

ORCID 0000-0001-9368-8657

\begin{abstract}
Purpose of review

Hereditary spastic paraplegias are a genetically heterogeneous group of neurological disorders. Patients present lower limb weakness and spasticity, complicated in complex forms by additional neurological signs. We review here the major steps towards understanding the molecular basis of these diseases made over the last 10 years.
\end{abstract}




\section{Recent findings}

Our perception of the intricate connections between clinical, genetic and molecular aspects of neurodegenerative disorders has radically changed in recent years, thanks to improvements in genetic approaches. This is particularly true for hereditary spastic paraplegias, for which $>60$ genes have been identified, highlighting (i) the considerable genetic heterogeneity of this group of clinically diverse disorders, (ii) the fuzzy border between recessive and dominant inheritance for several mutations and (iii) the overlap of these mutations with other neurological conditions in terms of their clinical effects. Several hypotheses have been put forward concerning the pathophysiological mechanisms involved, based on the genes implicated and their known function, and based on studies on patient samples and animal models. These mechanisms include mainly mitochondrial impairment, abnormal intracellular trafficking, changes to endoplasmic reticulum shaping and defects affecting lipid metabolism, lysosome physiology, autophagy, myelination and development. Several causative genes affect multiple of these functions, which are, most of the time, interconnected.

\section{Summary}

Recent major advances in our understanding of these diseases have revealed unifying pathogenic models that could be targeted in the much-needed development of new treatments.

\section{Keywords}

Hereditary spastic paraplegia, motor neuron, pyramidal syndrome, neurodegenerative diseases, intracellular trafficking, neurological diseases

\section{Acknowledgments}

We thank Drs F Mochel, F Darios, KH El-Hachimi and V Anquetil for fruitful discussions. The authors' work is funded by the European Union H2020 program (SOLVE-RD, to GS), the 
Spastic Paraplegia Foundation [US] (to GS), the Association Strümpell-Lorrain [FR] (to GS), the Agence Nationale de la Recherche [FR] (Spatax-Quest, to GS) and the E-Rare Program (Prepare, to GS). MB and SM held PhD fellowships from the ED3C Doctoral School (France) and the Fundação para a Ciência e a Tecnologia (Portugal), respectively.

\section{Conflict of interest}

The authors have no conflict of interest to declare.

\section{Human and animal rights and informed consent}

This article is a review and reports only studies approved by editorial boards based on peer reviews. When we cited our own work, all the procedures performed in the studies involving human materials or animals were conducted in accordance with the ethical standards of our institution, with informed consent obtained from patients, and approval from ethics committees.

\section{Introduction}

Hereditary spastic paraplegias (HSPs) are a large heterogeneous group of inherited neurodegenerative diseases. Patients present progressive spasticity and weakness, predominantly affecting the lower limbs [1].

The initial symptoms are subtle. Patients generally complain of frequent falls, with stiff legs, cramps and an abnormal or unstable gait. Disease progression is usually slow, but often leads to patients requiring assistance in the form of canes, walkers or wheelchairs as their gait becomes increasingly spastic and additional signs appear. Most patients display similar clinical 
features, including bilateral spasticity of the legs that is particularly marked on walking, a weakness of the muscles, leg hypertonicity, hyperreflexia and positive Babinski sign. Other frequently reported symptoms include bladder dysfunction, pes cavus and a loss of vibratory sensation at the ankles. The disease is considered to be uncomplicated, or pure, if these signs and symptoms are the only clinical features observed. By contrast, additional symptoms are identified in complex or complicated forms. These symptoms may be neurological or extraneurological and include cognitive/mental impairment, cerebellar ataxia, peripheral neuropathy, epilepsy, optic atrophy, retinal alterations, cataracts, dystonia and parkinsonism $[2]$.

One of the common hallmarks of these diseases, based on the description of small numbers of pathological cases however, is axonal degeneration, which is most marked in the longest tracts. Postmortem analyses of patient tissues have revealed axonal degeneration to be most severe at the distal ends of the corticospinal tracts, fasciculus gracilis fibers, and spinocerebellar tracts, corresponding to the longest motor and sensory axons of the central nervous system. Observations suggesting that degeneration began at the distal end of the axons, progressing towards the cell body, led to the hypothesis that these diseases were dying-back axonopathies $[3,4]$. Long axons with a unique, highly polarized architecture are commonly affected, suggesting a possible role for abnormalities of cellular processes in HSP, such as axonal transport, intracellular trafficking and mitochondrial functions; this hypothesis was confirmed by the implication of genes involved in these functions in these diseases $[5,6]$. However, other brain structures, such as the cerebellum, cerebral cortex, basal ganglia and white matter (including the corpus callosum), may be affected in complicated forms, as shown by postmortem examinations [7] and brain imaging [8]. A simple dying back of the long axons is thus an inadequate unifying model. Other mechanisms must also be involved, to explain the degeneration of other brain structures. 


\section{Considerable genetic heterogeneity}

HSP has an estimated global prevalence of 4.26/100,000, with reported values ranging from 0.9-9.6/100,000, depending on the mode of inheritance and the geographic area considered [ $\left.9^{*}\right]$. The genetic basis of HSP is extremely diverse, with all possible classical modes of inheritance reported. Autosomal dominant (AD) forms of HSP (ADHSP) predominate in Western countries, whereas autosomal recessive (AR) forms (ARHSP) are common in inbred populations, while X-linked and maternally inherited forms are rare. However, isolated cases are often seen in clinical practice. Such cases may correspond to inherited forms that remain undiagnosed due to the de novo nature of the variants involved, the death of the transmitting parent before identification/clinical expression of the variant, variable expressivity and, particularly for the dominant forms, low or age-dependent penetrance of the mutation.

The observed clinical heterogeneity can be at least partly explained by the immense genetic heterogeneity. Mutations or rearrangements of at least 64 genes (the SPastic Gait/Gene or SPG genes) have been reported to date, and another 13 associated loci have been localized on chromosomal regions (Table 1) [10-13]. The study of Novarino et al. [14**] highlights this considerable heterogeneity: these authors identified 18 new genes responsible for recessive forms of HSP, through a combination of exome-sequencing, whole-genome linkage analysis, bioinformatics and the functional validation of several genes in zebrafish models. Mutations of more than 30 other genes have been shown to mimic HSP in diseases including spastic paraplegia as a clinical feature. Indeed, Novarino et al. described an "HSPome" network of 589 genes, all of which are good candidate genes for HSP, as shown by the identification of mutations of three of these genes on candidate gene screening [14**]. However, these additional genes lie beyond the scope of this review and will not be considered further here, 
except for few relevant cases [10]. Several genes have been found mutated in single families only, and must therefore be considered as HSP-related genes with caution until functional studies or secondary cases are published.

\section{Autosomal dominant forms}

Twenty-two HSP loci/genes have been associated with ADHSP. Age at onset varies considerably and most cases are relatively pure. The dominant forms are mostly caused by variants or rearrangements of the SPAST (SPG4) gene, which account for 17-79\% of all ADHSP cases. These variants cause a relatively pure form of HSP [15-18], sometimes with cognitive impairment [19,20]. Causal variants of ATL1 (SPG3A), REEP1 (SPG31) and KIF5A (SPG10) are also common. Together with the SPAST variants, they are responsible for the disease in about $50-60 \%$ of families with dominant forms of HSP [15-18]. ATL1 mutations are principally associated with early onset, before the age of 10 years. Variants of NIPA1/SPG6, WASHC5/SPG8, RTN2/SPG12, HSP60/SPG13, BSCL2/SPG17 and CPT1C/SPG73 are much less common.

\section{Autosomal recessive forms}

ARHSP has been shown to be associated with 50 loci (Table 1), in which 45 causal genes have been identified as mutated [10]. SPG11 is the gene most frequently mutated, accounting for about $21 \%$ of cases and causing a complex form of the disease [21]. Other frequent causes, accounting for about $20 \%$ of the ARHSP families in total, are variants of the CYP7B1 (SPG5), SPG7 and ZFYVE26 (SPG15) [15-18] genes. In several countries, variants in the SACS gene responsible for the spastic ataxia of Charlevoix-Saguenay have also been implicated in ARHSP. In addition, CAPN1 (SPG76) loss-of-function mutations have recently been identified in a 
number of families in multiple successive publications, suggesting that their frequency in ARHSP forms are probably higher than initially thought [22-26].

\section{X-linked and mitochondrial forms}

Five X-linked loci have already been associated with HSP, and the causal gene has been identified for three of these loci: L1CAM (SPG1), PLP1 (SPG2) and SLC16A2 (SPG22). These X-linked forms remain rare in HSP cohorts, but SPG1 has been implicated in the MASA and CRASH syndromes in children, whereas SPG2 which is allelic to Pelizaeus-Merzbacher disease, can cause late-onset pure HSP in women.

MT-ATP6 is located on the mitochondrial DNA and is, therefore, maternally inherited. It has also been associated with an HSP-like phenotype in a single family [27]. It encodes one of the subunits of ATP synthase (Complex V), the final enzyme in oxidative phosphorylation (OXPHOS). As no SPG number was attributed to this gene and as the clinical description associated with variants of this gene is rare, it is not included in Table 1.

\section{Mixed inheritance forms}

One of the most intriguing findings in this field in recent years is the multiple modes of inheritance reported for variants of a number of these causal genes, including $R E E P 2 / \mathrm{SPG} 72$, $A L D H 18 A 1 /$ SPG9 and KIF1A/SPG30 [28*,29-31]. For SPG72, dominant mutations have a dominant-negative effect on the wild-type protein, preventing REEP2 binding to the endoplasmic reticulum (ER) membrane and resulting in a loss of function, as observed for recessive mutations in the same gene [28*]. For SPG30, dominant transmission of missense variants is based on a dominant-negative effect disrupting KIF1A binding to microtubules [32*]. In recessive HSP cases, the phenotype associated to KIF1A missense variants is less severe. The frequency of KIFIA mutations with an AD mode of inheritance remains unclear, 
but such mutations may be common in sporadic patients of ADHSP given the high frequency of de novo cases.

Other forms seem to display mostly one main mode of inheritance. For example, ATL1/SPG3A has been reported to display mainly autosomal dominant transmission, although at least one causal variant has been shown to be recessive [33]. Other causal genes are mostly recessive, but several reports have exposed possible dominance for some variants, as demonstrated for SPG7 [34,35*] and, more recently, for ERLIN2/SPG18/SPG37 [36]

\section{Sporadic forms}

Most cases of spastic paraplegia are sporadic. Once other differential diagnoses, such as structural abnormalities of the brain or spinal cord, infection by human T-lymphotrophic virus type 1 [HTLV1], multiple sclerosis, dopa-responsive dystonia, amyotrophic or primary lateral sclerosis, have been excluded by MRI and biochemical analyses, mutations should be sought in genes known to be associated with or related to HSP. Such analyses have revealed that a substantial proportion of apparently sporadic cases are actually genetic. SPAST, ATL1 and $S P G 11$ variants are frequent, as are KIF1A variants, for which large numbers of de novo cases have already been reported. Gonadal mosaicism has also been reported for SPG4 [37].

Clinical variability and overlap with other neurological conditions, phenotype-genotype correlations

Age-at-onset is variable for HSP, with the first manifestations of the disease occurring anyway between early infancy and old age. There may also be considerable variability in age at HSP onset within a given family [38]. Mutations of several ADHSP genes, including SPAST [39*], REEP1 [40] and BSCL2 [41,42], display incomplete penetrance, suggesting an effect of as yet unknown modifying factors. Two SPG4 polymorphisms (p.S44L, p.P45Q) have been suggested 
to modulate or attenuate disease severity through changes in the stability of spastin (SPAST/SPG4 gene product) isoforms; they may act as weak mutations in association with other SPAST alterations [43]. Penetrance and age-at-onset have also been shown to depend on gender for SPG4 [39*].

HSP progression is also highly variable. Some patients present disabilities that progress relatively little over many years, whereas the disease rapidly worsens in others. The rate of progression may also change over time in individual patients. For example, many patients display a rapid worsening during adolescence, with slower rates of progression thereafter. The disease often eventually seems to stabilize, probably due to a number of factors, including possible functional compensation through neuroplasticity [2]. Earlier disease onset has also been reported to be associated with a less severe presentation [18].

Further variability is observed for clinical presentation, with most of the causal genes associated with both pure and complex forms of the disease. The "additional" neurological and extraneurological signs observed in complex forms are also highly variable, even within the same family. However, clinical signs of intellectual disability and ataxia are frequently reported. For example, variants of the $S A C S$ gene usually cause a spastic ataxia phenotype, but several patients have been identified with mutations of this gene and phenotypes at the extreme ends of the spastic ataxia spectrum: either isolated ataxia or spasticity [44,45]. It is often difficult to classify patients on this spectrum of spastic ataxia phenotypes. For example, GBA2 mutations may cause conditions that can be classified as ataxia or HSP [46,47]. Many patients with HSP display peripheral neuropathy, highlighting the overlap with Charcot-Marie-Tooth disease. As the number of patients with each mutation increases, so does the phenotypic spectrum of each genetic entity and the overlap with other neurological conditions. There is an increasing number of genes primarily associated with other neurodegenerative disorders that are sometimes considered as differential diagnoses for HSP, such as leukodystrophies, that are 
now being shown to be responsible for pure forms of spastic paraplegia. HSP and leukodystrophies have at least three causal genes in common (PLP1, HSPD1, GJC2), and at least eight other genes have been reported to mimic HSP in some cases $(A B C D 1, \mathrm{~A} D A R$, EIF2B5, GJA1, IFIH1, RNASEH2B, SAMHD1 and TUBB4A). This is the case, for example, for ATP13A2 (SPG78/PARK9) which has recently been shown to be associated with HSP, but was previously associated only with Parkinson's disease [48]. Loss of function mutations in another gene possibly related to Parkinson's disease, UCHL1 (SPG79/PARK5), has also been found in spastic ataxia patients [49]. Neurodegeneration with iron accumulation is also caused by defects of genes that have been implicated in HSP: $C 9$ orf 72 and $F A 2 H$. Another recent example relates to $A C O 2$ mutations, initially associated with infantile cerebellar-retinal degeneration combining optic atrophy, retinal degeneration, severe encephalopathy, epilepsy, and cerebellar ataxia, which have now been associated with mild to complex HSP variably associating intellectual disability, microcephaly and optic atrophy with no phenotype-genotype correlations [50,51]. Conversely, mutations of some HSP genes have also been shown to cause other diseases. For example, SPG11 mutations are also associated with amyotrophic lateral sclerosis (ALS) and Charcot-Marie-Tooth disease [52-54], and KIF1A mutations have been linked to hereditary autonomic neuropathy or mental retardation [30-32,55-57].

These wide spectra for age-at-onset, progression and symptoms, together with their clinical overlap with other neurological diseases and the high degree of genetic heterogeneity, make it difficult to establish phenotype-genotype correlations. The various presentations of the disease are sometimes associated with different modes of inheritance. For example, heterozygous variants of HSPDI are associated with HSP, whereas homozygous missense variants are responsible for hypomyelinating leukodystrophy type 4 [58]. Another illustration is provided by TFG, for which a heterozygous variant in the P/Q-rich domain causes autosomal dominant hereditary motor and sensory neuropathy [59], whereas homozygous variants of the coiled-coil 
and PB1 domains have been linked to HSP $[60,61]$, suggesting that different pathogenic mechanisms may be involved. Similarly, the nature, location and zygosity of KIF1A mutations explain the phenotype: hereditary autonomic neuropathy results from a complete loss of function [56], whereas homozygous missense mutations cause a relatively pure HSP phenotype [30,57], and heterozygous missense mutations in the motor domain result in dominant negative effects on the kinesin protein, accounting for early-onset complex HSP [32*]. For SPG7, the p.A510V mutation is more often associated with ataxia than with spastic paraplegia [62*]. By contrast, mutations of PNPLA6 and ALDH18A1 underlie multiple phenotypes and/or are transmitted by multiple modes of inheritance, sometimes without spasticity, and with no clustering according to the nature or location of the mutations $\left[63^{*}, 29\right]$.

\section{Pathogenic mechanisms}

We still know little about the mechanisms underlying the degeneration of distal portions of the corticospinal tracts, and of other brain structures in complex forms. However, the identification of a number of causal genes and determination of the functions of their products have suggested that alterations to intracellular trafficking may be a common element. The affected functions include active axonal transport, the activities of the endolysosomal system, organelle shaping, and lipid metabolism. In some clinicogenetic forms, effects on myelination, mitochondrial functions and axon guidance have also been observed. Several HSP-related proteins are known to be involved in multiple of these pathways, which may well be interconnected. It is, therefore, often difficult to determine which dysfunction is the principal cause of the neurodegeneration for a given gene/protein.

\section{Intracellular active transport}


Three HSP proteins perfectly illustrate the requirement of intracellular trafficking for the maintenance of long axons. Mutations of KIF5A (SPG10) result in a lower affinity of the kinesin-1 motor protein encoded by this gene for microtubules and a decrease in the gliding velocity of microtubule-dependent anterograde axonal transport [64]. The SPG30 and SPG58 forms are caused by mutations of the genes encoding the KIF1A and KIF1C proteins, respectively. Both dominant and recessive mutations have been described for SPG30, with a dominant negative effect disrupting KIF1A binding to microtubules underlying dominant transmission [32*]. For SPG58, all the mutations identified to date affect the ATPase and the microtubule-binding domains of KIF1C and minor or subclinical signs can be observed in heterozygous parents of homozygous patients [65]. A spontaneous mutation of KIF1C in Charolais cattle has been shown to cause a frequent spastic ataxia with severe demyelination in the brain $\left[66^{*}\right]$.

Many other HSP proteins may be involved in intracellular trafficking. Spastin (SPAST/SPG4), an adenosine triphosphatase (ATPase), has three domains with different cellular activities: a microtubule-interacting domain, a microtubule-interacting and endosomal trafficking domain (MIT) and an ATPase (AAA) domain with microtubule-severing activity [67]. Spastin exists in two main isoforms: M1, which is mostly associated with the ER, and M87, which is cytoplasmic $[68,69]$. SPAST knockout mice have focal swellings of the spinal cord axons, with abnormal accumulations of organelles and cytoskeletal components, suggesting an impairment of axonal transport associated with mild late motor impairment with no detectable neuron loss [70]. These defects occur close to growth cones, in regions of transition between stable and dynamic microtubules. Spastin localizes to areas of the cytoplasm important for microtubule dynamics [71], and the overproduction of this protein results in microtubule depletion in cultures of mammalian cells [72] and disruption of the microtubule network in Drosophila melanogaster [73,74] and Caenorhabditis elegans [75]. These findings 
led to suggestions that the axon degeneration observed in spastic paraplegia was due to defective axonal microtubule organization. Spastin has several other functions (some of which will be discussed below). In particular, it interacts with CHMP1B [76], which is associated with the endosomal sorting complex of the ESCRT transport machinery. This complex is involved in several pathways, and plays a role in the completion of cell division. The M87 isoform is required for cytokinesis and the microtubule disruption that normally occurs during this process is impaired in its absence [68,77]. Truncating and missense mutations of Spastin are thought to result in a loss of function through haploinsufficiency or dominant negative effects.

Spastin interacts with Atlastin-1 (SPG3A) [78,79], a transmembrane dynamin/guanylatebinding protein. Its subcellular distribution (ER, cis-Golgi, vesicular structures in axonal growth cones, varicosities and axonal branch points) [80,81] suggests a functional role in both intracellular trafficking and axonal development, consistent with the early onset of disease in SPG3A patients. Some atlastin-1 mutations affect the GTPase activity of the protein [81]. These mutations have been reported to affect the budding of vesicles from the ER, or their targeting to the Golgi apparatus, possibly due to impairment of the interaction of Atlastin-1 with p24, a protein of the $\mathrm{p} 24 / \mathrm{emp} / \mathrm{gp} 25 \mathrm{~L}$ protein family [82].

Another HSP protein, Spartin (SPG20), has been implicated in epidermal growth factor receptor [EGFR] endocytosis and transport [83]. It is found in synapse-like structures, neurites and the trans-Golgi network of differentiated neurons [84]. Maspardin (SPG21) is found in endosomes and trans-Golgi vesicles and is thought to be involved in membrane sorting [85]. The NIPA1 protein (SPG6) is a transmembrane protein specific to neurons, present in the early endosomal compartment and on the plasma membrane, where it is thought to transport magnesium [86]. Pathogenic missense mutations of the gene encoding this protein prevent its transfer from endosomes to the plasma membrane. This effect probably results from a dominant-negative gain of function, because large gene deletions do not cause HSP in humans. 
NIPA1 ortholog in Drosophila (Spict) interacts with bone morphogenetic protein (BMP) receptors, promoting their internalization [87]. BMP signaling is required for normal assembly of the microtubule cytoskeleton, so NIPA1 mutations may also interfere with axonal transport.

Abnormal trafficking has also been implicated in several other disorders closely related to HSP, such as Charcot-Marie-Tooth disease, in which patients present neuropathies affecting the long axons of the peripheral nervous system, and ALS. For example, truncating mutations of $A L S 2$, which encodes Alsin, have been implicated in various lower and upper motor neuron disorders with different clinical presentations $[88,89]$. The knockout of Alsin in mouse leads to distal axonopathy [90] and abnormal trophic factor (IGF1, BDNF) receptor transport [91]. ALS2 missense variants are associated with Alsin delocalization from the endosomes and greater susceptibility to induced apoptotic stress in vitro [92].

Together, these observations suggest that alterations to intracellular trafficking are particularly deleterious for long axons.

\section{Endoplasmic reticulum shaping}

The ER is a membrane-bound organelle consisting of the nuclear envelope, sheets forming the rough ER and a tubular network connected to other organelles throughout the cell. It has many different functions (protein and lipid synthesis, calcium homeostasis regulation and exchange of molecules with other organelles), depending on its morphology. Long-axon neurons appear to be particularly dependent on the formation and maintenance of the ER, as several HSP proteins are involved in these processes. Indeed, the three most frequent autosomal dominant HSPs are caused by mutations of the $S P G 3 A, S P A S T / \mathrm{SPG} 4$ and REEP1/SPG31 genes, encoding Atlastin-1, Spastin and REEP1, respectively. These proteins insert their hairpin loop domains into the membrane of the tubular ER, thereby contributing to the shaping of this structure. 
Atlastin-1 mediates homotypic fusions of ER tubules, generating the three-way junctions between ER tubules that shape the characteristic morphology of the ER in the periphery of the cell. Atlastin-1 loss results in changes to the morphology of the ER [93-95]. Spastin M1 interacts with Atlastin-1 and REEP1, and links the microtubule cytoskeleton to the ER tubule network [96]. The REEP1 and REEP 2-4 proteins also interact with microtubules [97,98], and these interactions are believed to underlie the formation and stabilization of the ER tubular network. REEP1 depletion decreases the number of ER three-way junctions [69], and losses of REEP2 function cause ER sheet expansion [28*]. Other HSP-related proteins, such as ARL6IP1 (SPG61), RAB3GAP2 (SPG69) and Reticulon 2 (SPG12), are also involved in ER shaping. Depletion of the Drosophila ortholog of Reticulon 1, Rtnl1, leads to ER sheet expansion and a loss of tubular ER markers from distal motor axons [99]. Axonal continuity and the correct axonal transport of ER tubules were recently shown to require ER shaping genes, such as Rtnll, in Drosophila [100*].

These findings suggest that long axons are highly sensitive to changes in the morphology of the ER tubular network. However, the ER has many functions and it remains unclear which are the most relevant to the pathophysiology of HSP. Changes in the morphology of the ER have recently been shown to lead to a loss of contact between the ER and other organelles, consistent with the probable impairment of the functions of membranous contact sites in several HSPs [101*]. Changes in ER shaping may also underlie defects of lipid synthesis and metabolism, as the ER plays a crucial role in these functions.

\section{Lipid metabolism}

Many in vitro and in vivo models of HSP display alterations to lipid metabolism. Indeed, several HSP-related proteins have been implicated in regulating the number and size of lipid droplets (LDs). These organelles are the site of lipid storage within the cell. The changes to 
LDs dynamics in HSP may reflect the changes in ER shaping, as LDs are formed from the ER [102]. The modulation of Atlastin-1, Spastin or REEP1 expression has consistently been shown to lead to changes in the number or size of LDs [103-105]. Spastin M1 downregulation (or the expression of a dominant-negative variant) results in the presence of smaller numbers of LDs in nerves, skeletal muscles and fat bodies in a Drosophila model [105**]. Conversely, the cooverproduction of REEP1 and Atlastin-1 in mammalian cells results in the presence of very large LDs [104], and REEP1 has been shown to play a role in regulating LDs both in vitro and in vivo $[103,106]$. Furthermore, postmortem analyses of the brains of SPG54 patients with DDHD2 mutations have revealed the accumulation of large LDs in cells [107], and the absence of Spartin (SPG20) has been shown to be associated with the presence of larger numbers of LDs in the adipose tissue of female KO mice [108]. Finally, Seipin (SPG17) is an integral ER protein involved in LD biogenesis. Alterations to the LDs in axons may, therefore, contribute to the pathophysiology of HSP.

Some cases of HSP are caused by mutations of genes encoding proteins directly involved in lipid metabolism. SPG26 is caused by mutations of B4GALNT1 [109], which encodes an enzyme involved in ganglioside synthesis. A loss of the function of this enzyme leads to GM3 ganglioside accumulation in cells [110]. Loss-of-function mutations affecting the GBA2 glucocerebrosidase enzyme (SPG46) [46,47] lead to glucosylceramide accumulation, resulting in changes to cytoskeletal dynamics in animal models [111]. SPG5 is caused by mutations of the gene encoding an enzyme involved in cholesterol metabolism, CYP7B1, and affected patients have high levels of oxysterol substrates in the plasma membrane and cerebrospinal fluid [112]. Finally, losses of function of the fatty acid hydroxylases PNPLA6, FA2H, DDHD1 and DDHD2 also lead to HSP, but the reasons for this are less well understood.

Overall, these findings suggest that the correct regulation of lipid metabolism is crucial for the neurons affected in HSP. 


\section{Endolysosomal trafficking pathway}

Endolysosomal dysfunctions have been reported in various HSP models in recent years. Such dysfunctions may be associated with changes to lipid metabolism, as in lysosomal storage diseases (LSD), a group of diseases in which lipids and other materials accumulate in lysosomes due to a primary dysfunction of these organelles [113]. An accumulation of undigested materials reminiscent of that observed in LSD has been reported in some HSP models. This finding is of particular interest because patients with LSD sometimes display spasticity, which can lead to a misdiagnosis of HSP [114]. Electron microscopy analyses of the fibroblasts of SPG48 patients have revealed an accumulation of membrane material in the endolysosomes [115]. The gene mutated in SPG48 encodes AP5Z1, a subunit of the AP-5 complex involved in vesicular-mediated trafficking of cargoes. This protein interacts with Spatacsin (SPG11) and Spastizin (SPG15) [115]. The SPG11 and SPG15 HSP subforms are clinically indistinguishable. The loss of either of these proteins impairs the autophagic lysosome reformation (ALR) process [116]. Material has been shown to accumulate in the endolysosomal pathways of both SPG11 and SPG15 mice [117-119]. This material was recently identified as simple gangliosides in SPG11 mice, and its accumulation results from the impairment of lysosome reformation due to the loss of Spatacsin $\left[120^{* *}\right]$. The prevention of ganglioside accumulation prevented neuronal cell death in vitro and corrected the motor phenotype of a zebrafish model of the SPG11 disease, demonstrating the deleterious effects on neurons of ganglioside accumulation in lysosomes. Such an accumulation is also observed in various LSDs characterized by neurodegeneration and in more common neurodegenerative diseases, such as Alzheimer's disease [121,122].

It was recently suggested that defective endosome fission due to a loss of contact between the ER and endosomes might disturb the trafficking of lysosomal enzymes, accounting for the 
lysosomal dysfunctions observed in many forms of HSP [101*]. Lysosomal dysfunctions may be associated with a decrease in degradation capacity.

Thus, lysosomal functions appear to be crucial for neurons, and lysosomal dysfunction may impair a number of pathways in which these organelles are involved, including autophagy. These changes would also contribute to alterations to lipid metabolism and the shaping of organelles, such as the ER, showing then the links between these cellular functions altered in HSPs

\section{Other functions}

A few of the identified HSP genes encode proteins associated with mitochondrial functions. These genes include HSPD1 (HSP60), ACO2 and SPG7. Missense mutations of the gene encoding mitochondrial HSP60 cause SPG13, through the disruption of HSP60 activity and mitochondrial quality control [123]. The gene mutated in SPG7 encodes Paraplegin, a member of the mitochondrial AAA protease family. Paraplegin-deficient mice present an abnormal accumulation of mitochondria in axons, leading to motor deficits, followed by axon swelling and neurodegeneration [124]. ACO2 mutations impair the Krebs cycle through a reduction of the aconitase enzyme activity and a subsequent impaired mitochondrial respiration in lymphoblastoid cell lines of patients [50,51].

The association of the microtubule-associated protein Spartin (SPG20) with mitochondria is also lost following mutation of the corresponding gene [125], which suggests that Troyer syndrome (SPG20) may result from a defect of microtubule-mediated mitochondrion transport. Finally, SPG77 is caused by mutations of FARS2, which encodes a mitochondrial phenylalanyl tRNA synthetase (mtPheRS) [126]. 
Mitochondrial functions may also be altered indirectly in other HSPs. In patients with mutations affecting REEP1, the interactions between REEP1 and mitochondrial PGAM5 are abnormal, resulting in alterations to mitochondrial morphology [127*].

Abnormal development is clearly observed in two clinically different X-linked forms of HSP: SPG1 and SPG2. The cell surface glycoprotein L1-CAM, which is mutated in SPG1, plays a crucial role in the migration and differentiation of neurons. Alterations to this protein in patients and knockout mice are associated with developmental phenotypes (e.g., corpus callosum hypoplasia, adducted thumbs, psychomotor retardation, hydrocephalus, a small corticospinal tract and poor associations of non-myelinating Schwann cells) due to a lack of axonal guidance [128]. Mutations of $P L P 1$, encoding an integral protein of myelin and involved in the maturation of oligodendrocytes, account for the occurrence of dysmyelination and axonal degeneration in the central nervous system of SPG2 patients and of cases with the allelic Pelizaeus-Merzbacher disease. PLP1 loss-of-function mutations in mice is associated with abnormal oligodendroglial dynamics, inflammation and degeneration of long axons at later stages [129].

Mutations of other HSP genes may result in developmental defects as well. This might be the case in HSP entities with early age at onset and/or clinical presentations combining spasticity with early cognitive deficiencies. Overt motor or brain developmental defects have been reported for knockdowns of SPAST (SPG4), SPG3A, SPG11, SPG15 and GBA2 (SPG46) in zebrafish, regardless of their known implication in neurodevelopment $\left[130^{* *}, 131,46\right]$.

\section{Conclusions}

The growing use of next-generation sequencing is improving diagnosis, but also leading to the continual identification of new causal genes for HSP. The increasing number of HSP genes 
identified up to now highlights the extreme genetic heterogeneity of these disorders and their clinical and functional overlap with other neurological conditions. The challenge facing us in the genetics of HSP is explaining the clinical variability between patients carrying identical mutations, some of whom may develop a complex HSP, whereas others develop another neurological condition in which spasticity is no more than a minor element, if present at all.

There is still no specific treatment for preventing or slowing neuronal degeneration or dysfunction. Only symptomatic treatments based on antispasticity drugs, botulinum toxin or physiotherapy can help to improve the patient's quality of life [2]. Several studies in animal models have identified compounds or strategies that may improve phenotypes [132-136], but their transfer into patient care will require further characterization of their effects and the identification of useful biomarkers for demonstrating their beneficial activity, a process currently underway for SPG5 [137**,138*]. Finally, several HSP models display a number of different cellular dysfunctions, complicating identification of the primary dysfunction, or the dysfunction of greatest relevance to the disease. However, several common pathways relating to intracellular membrane dynamics (Figure 1) are affected in multiple HSPs, suggesting that it may be possible to develop therapies targeting these common elements in the future.

\section{References}

Papers of particular interest, published recently, have been highlighted as:

\footnotetext{
*of importance

**of major importance
} 
1. Harding AE. Classification of the hereditary ataxias and paraplegias. Lancet. 1983, 1:1151-1155.

2. Fink JK. Hereditary spastic paraplegia: clinico-pathologic features and emerging molecular mechanisms. Acta Neuropathol. 2013;126, 307-328.

3. Deluca GC, Ebers GC, Esiri MM. The extent of axonal loss in the long tracts in hereditary spastic paraplegia. Neuropathol Appl Neurobiol. 2004, 30:576-584.

4. Schwarz GA, Liu CN. Hereditary (familial) spastic paraplegia; further clinical and pathologic observations. AMA Arch Neurol Psychiatry. 1956;75, 144-162.

5. Blackstone C, Kane CJO, Reid E, O’Kane CJ, Reid E. Hereditary spastic paraplegias: membrane traffic and the motor pathway. Nat Rev Neurosci. 2011; 12, 31-42.

6. Salinas S, Proukakis C, Crosby A, Warner TT. Hereditary spastic paraplegia: clinical features and pathogenetic mechanisms. Lancet Neurol. 2008; 7, 1127-1138.

7. Denora PS, Smets K, Zolfanelli F, Ceuterick-de Groote C, Casali C, Deconinck T, Sieben A, Gonzales M, Zuchner S, Darios F, Peeters D, Brice A, Malandrini A,De Jonghe P, Santorelli FM, Stevanin G, Martin JJ, El Hachimi KH. Motor neuron degeneration in spastic paraplegia 11 mimics amyotrophic lateral sclerosis lesions. Brain. 2016;139(Pt 6):1723-34.

8. França MC, D’Abreu A, Maurer-Morelli CV, Seccolin R, Appenzeller S, Alessio A, Damasceno BP, Nucci A, Cendes F, Lopes-Cendes I. Prospective neuroimaging study in hereditary spastic paraplegia with thin corpus callosum. Mov Disord. 2007;22, 15561562.

9. *Ruano L, Melo C, Silva MC, Coutinho P. The global epidemiology of hereditary ataxia and spastic paraplegia: a systematic review of prevalence studies. Neuroepidemiology. 2014;42(3):174-83. This meta-analysis study reanalyzed 22 reports on $>\mathbf{1 4 , 5 0 0}$ 
patients from 16 countries, to estimate the global prevalence of hereditary ataxias and spastic paraplegias.

10. Tesson C, Koht J, Stevanin G. Delving into the complexity of hereditary spastic paraplegias: how unexpected phenotypes and inheritance modes are revolutionizing their nosology. Hum Genet. 2015;134, 511-538.

11. Hensiek A, Kirker S, Reid E. Diagnosis, investigation and management of hereditary spastic paraplegias in the era of next-generation sequencing. J Neurol. 2015;262, 16011612.

12. Parodi L, Fenu S, Stevanin G, Durr A. Hereditary spastic paraplegia: More than an upper motor neuron disease. Rev Neurol (Paris). 2017; 173:352-360

13. Parodi L, Coarelli G, Stevanin G, Brice A, Durr A. Hereditary ataxias and paraparesias: clinical and genetic update. Curr Opin Neurol. 2018;31(4):462-471.

14. **Novarino G, Fenstermaker AG, Zaki MS, Hofree M, Silhavy JL, Heiberg AD, Abdellateef M, Rosti B, Scott E, Mansour L, Masri A, Kayserili H, Al-Aama JY, AbdelSalam GMH, Karminejad A, Kara M, Kara B, Bozorgmehri B, Ben-Omran T, Mojahedi F, El Din Mahmoud IG, Bouslam N, Bouhouche A, Benomar A, Hanein S, Raymond L, Forlani S, Mascaro M, Selim L, Shehata N, Al-Allawi N, Bindu PS, Azam M, Gunel M, Caglayan A, Bilguvar K, Tolun A, Issa MY, Schroth J, Spencer EG, Rosti RO, Akizu N, Vaux KK, Johansen A, Koh AA, Megahed H, Durr A, Brice A, Stevanin G, Gabriel SB, Ideker T, Gleeson JG. Exome sequencing links corticospinal motor neuron disease to common neurodegenerative disorders. Science. 2014;343(6170):506-511. The authors analyzed a cohort of 55 consanguineous families with HSP by exome sequencing, with gene validation in zebrafish experiments in a few cases. They identified the cause of the disease in three quarters of the families as a defect of a known or new $(n=18)$ HSP gene. Bioinformatic analyses identified 589 interconnected genes, all 
candidates for HSP, some of which are overrepresented among the causal genes for neurodegenerative diseases.

15. Burguez D, Polese-Bonatto M, Scudeiro LAJ, Björkhem I, Schöls L, Jardim LB, Matte U, Saraiva-Pereira ML, Siebert M, Saute JAM. Clinical and molecular characterization of hereditary spastic paraplegias: A next-generation sequencing panel approach. J Neurol Sci. $2017 ; 383: 18-25$

16. Dong EL, Wang C, Wu S, Lu YQ, Lin XH, Su HZ, Zhao M, He J, Ma LX, Wang N, Chen WJ, Lin X. Clinical spectrum and genetic landscape for hereditary spastic paraplegias in China. Mol Neurodegener. 2018;13(1):36.

17. Chrestian N, Dupré N, Gan-Or Z, Szuto A, Chen S, Venkitachalam A, Brisson JD, Warman-Chardon J, Ahmed S, Ashtiani S, MacDonald H, Mohsin N, Mourabit-Amari K, Provencher P, Boycott KM, Stavropoulos DJ, Dion PA, Ray PN, Suchowersky O, Rouleau GA, Yoon G. Clinical and genetic study of hereditary spastic paraplegia in Canada. Neurol Genet. 2016;3(1):e122.

18. Schüle R, Wiethoff S, Martus P, Karle KN, Otto S, Klebe S, Klimpe S, Gallenmüller C, Kurzwelly D, Henkel D, Rimmele F, Stolze H, Kohl Z, Kassubek J, Klockgether T, Vielhaber S, Kamm C, Klopstock T, Bauer P, Züchner S, Liepelt-Scarfone I, Schöls L. Hereditary spastic paraplegia: Clinicogenetic lessons from 608 patients. Ann Neurol. 2016;79(4):646-58.

19. Ribaï P, Depienne C, Fedirko E, Jothy AC, Viveweger C, Hahn-Barma V, Brice A, Durr A. Mental deficiency in three families with SPG4 spastic paraplegia. Eur J Hum Genet. 2008;16(1):97-104.

20. Chamard L, Ferreira S, Pijoff A, Silvestre M, Berger E, Magnin E. Cognitive impairment involving social cognition in SPG4 hereditary spastic paraplegia. Behav Neurol. 2016;2016:6423461. 
21. Stevanin G, Azzedine H, Denora P, Boukhris A, Tazir M, Lossos A, Rosa AL, Lerer I, Hamri A, Alegria P, Loureiro J, Tada M, Hannequin D, Anheim M, Goizet C, GonzalezMartinez V, Le Ber I, Forlani S, Iwabuchi K, Meiner V, Uyanik G, Erichsen AK, Feki I, Pasquier F, Belarbi S, Cruz VT, Depienne C, Truchetto J, Garrigues G, Tallaksen C, Tranchant C, Nishizawa M, Vale J, Coutinho P, Santorelli FM, Mhiri C, Brice A, Durr A, SPATAX consortium. Mutations in SPG11 are frequent in autosomal recessive spastic paraplegia with thin corpus callosum, cognitive decline and lower motor neuron degeneration. Brain. 2008;131:772-784.

22. Gan-Or Z, Bouslam N, Birouk N, Lissouba A, Chambers DB, Vérièpe J, Androschuk A, Laurent SB, Rochefort D, Spiegelman D, Dionne-Laporte A, Szuto A, Liao M, Figlewicz DA, Bouhouche A, Benomar A, Yahyaoui M, Ouazzani R, Yoon G, Dupré N, Suchowersky O, Bolduc FV, Parker JA, Dion PA, Drapeau P, Rouleau GA, Ouled Amar Bencheikh B. Mutations in CAPN1 cause autosomal-recessive hereditary spastic paraplegia. Am J Hum Genet. 2016;98:1038-1046.

23. Wang Y, Hersheson J, Lopez D, Hammer M, Liu Y, Lee KH, Pinto V, Seinfeld J, Wiethoff S, Sun J, Amouri R, Hentati F, Baudry N, Tran J, Singleton AB, Coutelier M, Brice A, Stevanin G, Durr A, Bi X, Houlden H, Baudry M. Defects in the CAPN1 gene result in alterations in cerebellar development and cerebellar ataxia in mice and humans. Cell Rep. 2016;16(1):79-91.

24. Tadic V, Klein C, Hinrichs F, Münchau A, Lohmann K, Brüggemann N. CAPN1 mutations are associated with a syndrome of combined spasticity and ataxia. J Neurol. 2017;264(5):1008-1010.

25. Travaglini L, Bellacchio E, Aiello C, Pro S, Bertini E, Nicita F. Expanding the clinical phenotype of CAPN1-associated mutations: A new case with congenital-onset pure spastic paraplegia. J Neurol Sci. 2017;378:210-212. 
26. Kocoglu C, Gundogdu A, Kocaman G, Kahraman-Koytak P, Uluc K, Kiziltan G, Caglayan AO, Bilguvar K, Vural A, Basak AN. Homozygous CAPN1 mutations causing a spastic-ataxia phenotype in 2 families. Neurol Genet. 2018;4(1):e218.Verny C, Guegen N, Desquiret V, Chevrollier A, Prundean A., Dubas F, Cassereau J, Ferre M, AmatiBonneau P, Bonneau D, Reynier P, Procaccio V. Hereditary spastic paraplegia-like disorder due to a mitochondrial ATP6 gene point mutation. Mitochondrion. 2001;11:7075.

27. Verny C, Guegen N, Desquiret V, Chevrollier A, Prundean A, Dubas F, Cassereau J, Ferre M, Amati-Bonneau P, Bonneau D, Reynier P, Procaccio V. Hereditary spastic paraplegia-like disorder due to a mitochondrial ATP6 gene point mutation. Mitochondrion. 2011;11:70-75.

28. *Esteves T, Durr A, Mundwiller E, Loureiro JL, Boutry M, Gonzalez MA, Gauthier J, El-Hachim, KH, Depienne C, Muriel MP, Acosta Lebrigio RF, Gaussen M, Noreau A, Speziani F, Dionne-Laporte A, Deleuze JF, Dion P, Coutinho P, Rouleau GA, Zuchner S, Brice A, Stevanin G, Darios F. Loss of association of REEP2 with membranes leads to hereditary spastic paraplegia. Am J Hum Genet. 2014;94:268-277. This study illustrates how dominant and recessive inheritance can be explained by the effects and nature of mutations of the same HSP-related gene.

29. Coutelier M, Goizet, C, Durr, A, Habarou F, Morais S, Dionne-Laporte A, Tao F, Konop J, Stoll, M, Charles P, Jacoupy M, Matusiak R, Alonso I, Tallaksen C, Mairey M, Kennerson M, Gaussen M, Schule R, Janin M, Morice-Picard F, Durand CM, Depienne C, Calvas P, Coutinho P, Saudubray JM, Rouleau G, Brice A, Nicholson G, Darios F, Loureiro JL, Zuchner S, Ottolenghi C, Mochel F, Stevanin G. Alteration of ornithine metabolism leads to dominant and recessive hereditary spastic paraplegia. Brain. 2015; 138:2191-2205. 
30. Erlich Y, Edvardson S, Hodges E, Zenvirt S, Thekkat P, Shaag A, Dor T, Hannon GJ, Elpeleg O. Exome sequencing and disease-network analysis of a single family implicate a mutation in KIF1A in hereditary spastic paraparesis. Genome Res. 2011;21:658-664.

31. Lee JR, Srour M, Kim D, Hamdan FF, Lim SH, Brunel-Guitton C, Décarie JC, Rossignol E, Mitchell GA, Schreiber A, Moran R, Van Haren K, Richardson R, Nicolai J, Oberndorff KMEJ, Wagner JD, Boycott KM, Rahikkala E, Junna N, Tyynismaa H, Cuppen I, Verbeek NE, Stumpel CTRM, Willemsen MA, de Munnik SA, Rouleau GA, Kim E, Kamsteeg EJ, Kleefstra T, Michaud JL. De novo mutations in the motor domain of KIF1A cause cognitive impairment, spastic paraparesis, axonal neuropathy, and cerebellar atrophy. Hum Mutat. 2015;36:69-78.

32. *Cheon CK, Lim SH, Kim YM, Kim D, Lee NY, Yoon TS, Kim NS, Kim E, Lee JR. Autosomal dominant transmission of complicated hereditary spastic paraplegia due to a dominant negative mutation of KIF1A, SPG30 gene. Sci Rep. 2017,7:12527. In silico and in vitro experiments showing that heterozygous missense mutations affecting the conserved motor domain of KIF1A act through a dominant-negative effect on the wild-type protein.

33. Khan TN, Klar J, Tariq M, Anjum Baig S, Malik NA, Yousaf R, Baig SM, Dahl N. Evidence for autosomal recessive inheritance in SPG3A caused by homozygosity for a novel ATL1 missense mutation. Eur J Hum Genet. 2014;22:1180-1184.

34. Sánchez-Ferrero E, Coto E, Beetz C, Gámez J, Corao A, Díaz M, Esteban J, del Castillo E, Moris G, Infante J, Menéndez M, Pascual-Pascual S, López de Munaín A, GarciaBarcina M, Alvarez V. SPG7 mutational screening in spastic paraplegia patients supports a dominant effect for some mutations and a pathogenic role for p.A510V. Clin Genet. $2013 ; 83: 257-262$. 
35. *Klebe S, Depienne C, Gerber S, Challe G, Anheim M, Charles P, Fedirko E, Lejeune E, Cottineau J, Brusco A, Dollfus H, Chinnery PF, Mancini C, Ferrer X, Sole G, Destée A, Mayer JM, Fontaine B, de Seze J, Clanet M, Ollagnon E, Busson P, Cazeneuve C, Stevanin G, Kaplan J, Rozet JM, Brice A, Durr A. SPG7 Spastic paraplegia gene 7 in patients with spasticity and/or optic neuropathy. Brain. 2012;135(Pt 10):2980-2993. The authors show that heterozygous mutations in SPG7 can be associated with isolated autosomal dominant optic atrophy or late-onset cerebellar ataxia, whereas this gene is traditionally considered to cause recessive hereditary spastic ataxia.

36. Rydning SL, Dudesek A, Rimmele F, Funke C, Krüger S, Biskup S, Vigeland MD, Hjorthaug HS, Sejersted Y., Tallaksen C, Selmer KK, Kamm C. A novel heterozygous variant in ERLIN2 causes autosomal dominant pure hereditary spastic paraplegia. Eur $\mathrm{J}$ Neurol. 2018;25(7):943-e71.

37. Matthews AM, Tarailo-Graovac M, Price EM, Blydt-Hansen I, Ghani A, Drögemöller BI, Robinson WP, Ross CJ, Wasserman WW, Siden H, van Karnebeek CD. A de novo mosaic mutation in SPAST with two novel alternative alleles and chromosomal copy number variant in a boy with spastic paraplegia and autism spectrum disorder. Eur J Med Genet. 2017;60(10):548-552.

38. Santorelli FM, Patrono C, Fortini D, Tessa A, Comanducci G, Bertini E, Pierallini A, Amabile GA, Casali C. Intrafamilial variability in hereditary spastic paraplegia associated with an SPG4 gene mutation. Neurology. 2000;55:702-705.

39. *Parodi L, Fenu S, Barbier M, Banneau G, Duyckaerts C, Tezenas du Montcel S, Monin ML, Ait Said S, Guegan J, Tallaksen CME, Sablonniere B, Brice A, Stevanin G, Depienne C, Durr A on behalf of the SPATAX network. Spastic paraplegia due to SPAST mutations is modified by the underlying mutation and sex. Brain. 2018 (advance online). This work reports the largest cohort of SPG4 patients ( $n=842$ individuals) and reveals that 
onset occurs significantly earlier in missense mutation carriers and that penetrance is lower in women despite a greater disease severity in female patients.

40. Beetz C, Schüle R, Deconinck T, Tran-Viet KN, Zhu H, Kremer BPH, Frints SGM, Van Zelst-Stams WAG, Byrne P, Otto S, Nygren AOH, Baets J, Smets K, Ceulemans B, Dan B, Nagan N, Kassubek J, Klimpe S, Klopstock T, Stolze H, Smeets HJM, SchranderStumpel CTRM, Hutchinson M, Van De Warrenburg BP, Braastad C, Deufel T, PericakVance M, Schöls L, De Jonghe P, Züchner S. REEP1 mutation spectrum and genotype/phenotype correlation in hereditary spastic paraplegia type 31. Brain. 2008;131:1078-1086.

41. Musacchio T, Zaum A-K, Üçeyler N, Sommer C, Pfeifroth N, Reiners K, Kunstmann E, Volkmann J, Rost S, Klebe S. ALS and MMN mimics in patients with BSCL2 mutations: the expanding clinical spectrum of SPG17 hereditary spastic paraplegia. J. Neurol. $2017 ; 264: 11-20$

42. Windpassinger C, Auer-Grumbach M, Irobi J, Patel H, Petek E, Hörl G, Malli R, Reed J.a, Dierick I, Verpoorten N, Warner TT, Proukakis C, Van den Bergh P, Verellen C, Van Maldergem L, Merlini L, De Jonghe P, Timmerman V, Crosby AH, Wagner K. Heterozygous missense mutations in BSCL2 are associated with distal hereditary motor neuropathy and Silver syndrome. Nat Genet. 2004;36:271-276.

43. Schickel J, Pamminger T, Ehrsam A, Münch S, Huang X, Klopstock T, Kurlemann G, Hemmerich P, Dubiel W, Deufel T, Beetz C. Isoform-specific increase of spastin stability by N-terminal missense variants including intragenic modifiers of SPG4 hereditary spastic paraplegia. Eur J Neurol. 2007;14:1322-1328

44. Bouhlal Y, Amouri R, El Euch-Fayeche G, Hentati F. Autosomal recessive spastic ataxia of Charlevoix-Saguenay: an overview. Parkinsonism Relat Disord. 2011;17(6):418-422. 
45. Gregianin E1, Vazza G, Scaramel E, Boaretto F, Vettori A, Leonardi E, Tosatto SC, Manara R, Pegoraro E, Mostacciuolo ML. A novel SACS mutation results in non-ataxic spastic paraplegia and peripheral neuropathy. Eur J Neurol. 2013 ;20(11):1486-1491.

46. Martin E, Schüle R, Smets K, Rastetter A, Boukhris A, Loureiro JL, Gonzalez MA, Mundwiller E, Deconinck T, Wessner M, Jornea L, Oteyza AC, Durr A, Martin JJ, Schöls L, Mhiri C, Lamari F, Züchner S, De Jonghe P, Kabashi E, Brice A, Stevanin G. Loss of function of glucocerebrosidase GBA2 is responsible for motor neuron defects in hereditary spastic paraplegia. Am J Hum Genet. 2013;92:238-244.

47. Hammer MB, Eleuch-Fayache G, Schottlaender LV, Nehdi H, Gibbs JR, Arepalli SK, Chong SB, Hernandez DG, Sailer A, Liu G, Mistry PK, Cai H, Shrader G, Sassi C, Bouhlal Y, Houlden H, Hentati F, Amouri R, Singleton AB. Mutations in GBA2 cause autosomal-recessive cerebellar ataxia with spasticity. Am J Hum Genet. 2013;92(2):245251.

48. Kara E, Tucci A, Manzoni C, Lynch DS, Elpidorou M, Bettencourt C, Chelban V, Manole A, Hamed SA, Haridy NA, Federoff M, Preza E, Hughes D, Pittman A, Jaunmuktane Z, Brandner S, Xiromerisiou G, Wiethoff S, Schottlaender L, Proukakis C, Morris H, Warner T, Bhatia KP, Korlipara LV, Singleton AB, Hardy J, Wood NW, Lewis PA, Houlden H. Genetic and phenotypic characterization of complex hereditary spastic paraplegia. Brain. 2016;139(Pt 7):1904-1918.

49. Rydning SL, Backe PH, Sousa MML, Iqbal Z, Øye AM, Sheng Y, Yang M, Lin X, Slupphaug G, Nordenmark TH, Vigeland MD, Bjørås M, Tallaksen CM, Selmer KK. Novel UCHL1 mutations reveal new insights into ubiquitin processing. Hum Mol Genet. 2017;26(6):1031-1040.

50. Bouwkamp CG, Afawi Z, Fattal-Valevski A, Krabbendam IE, Rivetti S, Masalha R, Quadri M, Breedveld GJ, Mandel H, Tailakh MA, Beverloo HB, Stevanin G, Brice A, 
van IJcken WFJ, Vernooij MW, Dolga AM, de Vrij FMS, Bonifati V, Kushner SA. ACO2 homozygous missense mutation associated with complicated hereditary spastic paraplegia. Neurol Genet. 2018;4(2):e223.

51. Marelli C, Hamel C, Quiles M, Carlander B, Larrieu L, Delettre C, Sarzi E, Chretien D, Rustin P, Koenig M, Guissart C. ACO2 mutations: A novel phenotype associating severe optic atrophy and spastic paraplegia. Neurol Genet. 2018;4(2):e225.

52. Stevanin G, Santorelli FM, Azzedine H, Coutinho P, Chomilier J, Denora PS, Martin E, Ouvrard-Hernandez A-M, Tessa A, Bouslam N, Lossos A, Charles P, Loureiro JL, Elleuch N, Confavreux C, Cruz VT, Ruberg M, Leguern E, Grid D, Tazir M, Fontaine B, Filla A, Bertini E, Durr A, Brice A. Mutations in SPG11, encoding spatacsin, are a major cause of spastic paraplegia with thin corpus callosum. Nature Genet. 2007;39:366-372.

53. Orlacchio A, Babalini C, Borreca A, Patrono C, Massa R, Basaran S, Munhoz RP, Rogaeva EA, St George-Hyslop PH, Bernardi G, Kawarai T. SPATACSIN mutations cause autosomal recessive juvenile amyotrophic lateral sclerosis. Brain. 2010;133: 591598.

54. Montecchiani C, Pedace L, Lo Giudice T, Casella A, Mearini M, Gaudiello F, Pedroso JL, Terracciano C, Caltagirone C, Massa R, St George-Hyslop PH, Barsottini OGP, Kawarai T, Orlacchio A. ALS5/SPG11/KIAA1840 mutations cause autosomal recessive axonal Charcot-Marie-Tooth disease. Brain. 2016;139:73-85.

55. Hamdan FF, Gauthier J, Araki Y, Lin D-T, Yoshizawa Y, Higashi K, Park A-R, Spiegelman D, Dobrzeniecka S, Piton A, Tomitori H, Daoud H, Massicotte C, Henrion E, Diallo O; S2D Group, Shekarabi M, Marineau C, Shevell M, Maranda B, Mitchell G, Nadeau A, D'Anjou G, Vanasse M, Srour M, Lafrenière RG, Drapeau P, Lacaille JC, Kim E, Lee JR, Igarashi K, Huganir RL, Rouleau GA, Michaud JL. Excess of de novo 
deleterious mutations in genes associated with glutamatergic systems in nonsyndromic intellectual disability. Am J Hum Genet. 2011;88:306-316.

56. Riviere J-B, Ramalingam S, Lavastre V, Shekarabi M, Holbert S, Lafontaine J, Srour M, Merner N, Rochefort D, Hince P, Gaudet R, Mes-Masson A-M, Baets J, Houlden H, Brais B, Nicholson GA, Van Esch H, Nafissi S, De Jonghe P, Reilly MM, Timmerman V, Dion PA, Rouleau GA. KIF1A, an axonal transporter of synaptic vesicles, is mutated in hereditary sensory and autonomic neuropathy type 2. Am J Hum Genet. 2011;89:219230.

57. Klebe S, Lossos A, Azzedine H, Mundwiller E, Sheffer R, Gaussen M, Marelli C, Nawara M, Carpentier W, Meyer V, Rastetter A, Martin E, Bouteiller D, Orlando L, Gyapay G, El-Hachimi KH, Zimmerman B, Gamliel M, Misk A, Lerer I, Brice A, Durr A, Stevanin G. KIF1A missense mutations in SPG30, an autosomal recessive spastic paraplegia: distinct phenotypes according to the nature of the mutations. Eur $\mathrm{J}$ Hum Genet. 2012;20:645-649.

58. Magen D, Georgopoulos C, Bross P, Ang D, Segev Y, Goldsher D, Nemirovski A, Shahar E, Ravid S, Luder A, Heno B, Gershoni-Baruch R, Skorecki K, Mandel H. Mitochondrial hsp60 chaperonopathy causes an autosomal-recessive neurodegenerative disorder linked to brain hypomyelination and leukodystrophy. Am J Hum Genet. 2008;83(1):30-42.

59. Ishiura H1, Sako W, Yoshida M, Kawarai T, Tanabe O, Goto J, Takahashi Y, Date H, Mitsui J, Ahsan B, Ichikawa Y, Iwata A, Yoshino H, Izumi Y, Fujita K, Maeda K, Goto S, Koizumi H, Morigaki R, Ikemura M, Yamauchi N, Murayama S, Nicholson GA, Ito H, Sobue G, Nakagawa M, Kaji R, Tsuji S. The TRK-fused gene is mutated in hereditary motor and sensory neuropathy with proximal dominant involvement. Am J Hum Genet. 2012;91(2):320-329. 
60. Beetz C, Johnson A, Schuh AL, Thakur S, Varga RE, Fothergill T, Hertel N, BombaWarczak E, Thiele H, Nürnberg G, Altmüller J, Saxena R, Chapman ER, Dent EW, Nürnberg P, Audhya A. Inhibition of TFG function causes hereditary axon degeneration by impairing endoplasmic reticulum structure. Proc Natl Acad Sci USA. 2013;110(13):5091-5096.

61. Elsayed LEO, Mohammed IN, Hamed AAA, Elseed MA, Johnson A, Mairey M, Mohamed HESA, Idris MN, Salih MAM, El-sadig SM, Koko ME, Mohamed AYO, Raymond L, Coutelier M, Darios F, Siddig RA, Ahmed AKMA, Babi AMA, Malik HMO, Omer ZMBM, Mohamed EOE, Eltahir HB, Magboul NAA, Bushara EE, Elnour A, Rahim SMA, Alattaya A, Elbashir MI, Ibrahim ME, Durr A, Audhya A, Brice A, Ahmed AE, Stevanin G. Hereditary spastic paraplegias: Identification of a novel SPG57 variant affecting TFG oligomerization and description of HSP subtypes in Sudan. Eur J Hum Genet. 2017;25:100-110

62. *Coarelli G, Monin ML, Ewenczyk C, Fontaine B, Azulay JP, Calvas P, Benomar A, Ollagnon-Roman E, Sole G, Banneau G, Brice A, Stevanin G, Duyckaerts C, Durr A. SPG7 related spastic paraplegia differs according to the presence of the A510V variant: analysis of 81 patients. 21st International Congress of Parkinson's disease and movement disorders, Vancouver, June 4-8, 2017. Abstract in Mov Dis. 2017;32 (suppl 2): abstract 780. The authors report the largest series of cases with SPG7 mutations. They confirm that ataxia is more frequently associated with missense variants, particularly p.A510V, whereas spasticity is more frequently associated with truncating mutations.

63. *Synofzik M, Gonzalez MA, Marques Lourenço C, Coutelier M, Haack TB, Rebelo A, Hannequin D, Strom TM, Prokisch H, Kernstock C, Durr A, Schols L, Lima-Martinez MM, Farooq A, Schule R, Stevanin G, Marques W Jr, Zuchner S. PNPLA6 mutations 
cause Boucher-Neuhäuser and Gordon Holmes syndromes as part of a broad neurodegenerative spectrum. Brain. 2014;137:69-77. This study shows that PNPLA6 mutations are associated with a wide range of phenotypes.

64. Ebbing B, Mann K, Starosta A, Jaud J, Schöls L, Schüle R, Woehlke G. Effect of spastic paraplegia mutations in KIF5A kinesin on transport activity. Hum Mol Genet. $2008 ; 17: 1245-1252$.

65. Caballero Oteyza A, Battaloğlu E, Ocek L, Lindig T, Reichbauer J, Rebelo AP, Gonzalez MA, Zorlu Y, Ozes B, Timmann D, Bender B, Woehlke G, Züchner S, Schöls L, Schüle R. Motor protein mutations cause a new form of hereditary spastic paraplegia. Neurology. 2014;82:2007-2016.

66. *Duchesne A, Vaiman A, Frah M, Floriot S, Rodriguez S, Desmazières A, Fritz S, Beauvallet C, Albaric O, Venot E, Bertaud M, Saintilan R, Guatteo R, Esquerré D, Brice A, Darios F, Vilotte JL Stevanin G, Boichard D, El Hachimi KH. KIF1C loss of function disturbs oligodendrocyte plasma membrane in progressive ataxia of Charolais cattle and provides a reliable model for spastic ataxia in human. PLoS Genet. 2018;14(8):e1007550. KIF1C loss of function in Charolais cattle leads to spastic ataxia due to a demyelinating process resulting from oligodendrocyte dysfunction.

67. White SR, Evans KJ, Lary J, ole JL, Lauring B. Recognition of C-terminal amino acids in tubulin by pore loops in spastin is important for microtubule severing. J Cell Biol. 2007;176:995-1005.

68. Connell JW, Lindon C, Luzio JP, Reid E. Spastin couples microtubule severing to membrane traffic in completion of cytokinesis and secretion. Traffic. 2009;10:42-56.

69. Park SH, Zhu PP, Parker RL, Blackstone C. Hereditary spastic paraplegia proteins REEP1, spastin, and atlastin-1 coordinate microtubule interactions with the tubular ER network. J Clin Invest. 2010;120:1097-1110. 
70. Tarrade A, Fassier C, Courageot S, Charvin D, Vitte J, Peris L, Thorel A, Mouisel E, Fonknechten N, Roblot N, Seilhean D, Diérich A, Hauw JJ, Melki J. A mutation of spastin is responsible for swellings and impairment of transport in a region of axon characterized by changes in microtubule composition. Hum Mol Genet. 2006;15:35443558 .

71. Errico A, Claudiani P, D'Addio M, Rugarli EI. Spastin interacts with the centrosomal protein NA14, and is enriched in the spindle pole, the midbody and the distal axon. Hum Mol Genet. 2004;13:2121-2132.

72. Evans KJ, Gomes ER, Reisenweber SM, Gundersen GG, Lauring BP. Linking axonal degeneration to microtubule remodeling by spastin-mediated microtubule severing. J Cell Biol. 2005; 168:599-606.

73. Trotta N, Orso G, Rossetto MG, Daga A, Broadie K. The hereditary spastic paraplegia gene, spastin, regulates microtubule stability to modulate synaptic structure and function. Curr Biol. 2004;14:1135-1147.

74. Sherwood NT, Sun Q, Xue M, Zhang B, Zinn K. Drosophila spastin regulates synaptic microtubule networks and is required for normal motor function. PLoS Biol. 2004;2:e429.

75. Matsushita-Ishiodori Y, Yamanaka K, Ogura T. The C. elegans homologue of the spastic paraplegia protein, spastin, disassembles microtubules. Biochem Biophys Res Commun. 2007;359:157-162.

76. Reid E, Connell J, Edwards TL, Duley S, Brown SE, Sanderson CM. The hereditary spastic paraplegia protein spastin interacts with the ESCRT-III complex-associated endosomal protein CHMP1B. Hum Mol Genet. 2005;14:19-38. 
77. Yang D, Rismanchi N, Renvoisé B, Lippincott-Schwartz J, Blackstone C, Hurley JH. Structural basis for midbody targeting of spastin by the ESCRT-III protein CHMP1B. Nat Struct Mol Biol. 2008, 15:1278-1286.

78. Evans K, Keller C, Pavur K, Glasgow K, Conn B, Lauring B. Interaction of two hereditary spastic paraplegia gene products, spastin and atlastin, suggests a common pathway for axonal maintenance. Proc Natl Acad Sci USA. 2006;103:10666-10671.

79. Sanderson CM, Connell JW, Edwards TL, Bright NA, Duley S, Thompson A, Luzio JP, Reid E. Spastin and atlastin, two proteins mutated in autosomal-dominant hereditary spastic paraplegia, are binding partners. Hum Mol Genet. 2006;15:307-318.

80. Zhu PP, Patterson A, Lavoie B, Stadler J, Shoeb M, Patel R, Blackstone C. Cellular localization, oligomerization, and membrane association of the hereditary spastic paraplegia 3A (SPG3A) protein atlastin. J Biol Chem. 2003;278:49063-49071.

81. Zhu PP, Soderblom C, Tao-Cheng JH, Stadler J, Blackstone C. SPG3A protein atlastin1 is enriched in growth cones and promotes axon elongation during neuronal development. Hum Mol Genet. 2006;15:1343-1353.

82. Namekawa M, Muriel MP, Janer A, Latouche M, Dauphin A, Debeir T, Martin E, Duyckaerts C, Prigent A, Depienne C, Sittler A, Brice A, Ruberg M. Mutations in the SPG3A gene encoding the GTPase atlastin interfere with vesicle trafficking in the ER/Golgi interface and Golgi morphogenesis. Mol Cell Neurosci. 2007;35:1-13.

83. Bakowska JC, Jupille H, Fatheddin P, Puertollano R, Blackstone C. Troyer syndrome protein spartin is mono-ubiquitinated and functions in EGF receptor trafficking. Mol Biol Cell. 2007;18:1683-1692.

84. Robay D, Patel H, Simpson MA, Brown NA, Crosby AH. Endogenous spartin, mutated in hereditary spastic paraplegia, has a complex subcellular localization suggesting diverse roles in neurons. Exp Cell Res. 2006;312:2764-2777. 
85. Hanna MC and Blackstone C. Interaction of the SPG21 protein ACP33/maspardin with the aldehyde dehydrogenase ALDH16A1. Neurogenetics. 2009;10:217-228.

86. Goytain A, Hines RM, El Husseini A, Quamme GA. NIPA1(SPG6), the basis for autosomal dominant form of hereditary spastic paraplegia, encodes a functional $\mathrm{Mg}^{2+}$ transporter. J Biol Chem. 2007;282:8060-8068.

87. Wang X, Shaw WR, Tsang HT, et al.: Drosophila spichthyin inhibits BMP signaling and regulates synaptic growth and axonal microtubules. Nat Neurosci. 2007;10:177185.

88. Hadano S, Hand CK, Osuga H, Reid E, O'Kane CJ. A gene encoding a putative GTPase regulator is mutated in familial amyotrophic lateral sclerosis 2. Nat Genet. 2001;29:166-173.

89. Yang Y, Hentati A, Deng HX, Dabbagh O, Sasaki T, Hirano M, Hung WY, Ouahchi K, Yan J, Azim AC, Cole N, Gascon G, Yagmour A, Ben-Hamida M, Pericak-Vance M, Hentati F, Siddique T. The gene encoding alsin, a protein with three guanine-nucleotide exchange factor domains, is mutated in a form of recessive amyotrophic lateral sclerosis. Nat Genet. 2001;29:160-165.

90. Deng HX, Zhai H, Fu R, Shi Y, Gorrie GH, Yang Y, Liu E, Dal Canto MC, Mugnaini E, Siddique T. Distal axonopathy in an alsin-deficient mouse model. Hum Mol Genet. 2007;16:2911-2920.

91. Devon RS, Orban PC, Gerrow K, Barbieri MA, Schwab C, Cao LP, Helm JR, Bissada N, Cruz-Aguado R, Davidson TL, Witmer J, Metzler M, Lam CK, Tetzlaff W, Simpson EM, McCaffery JM, El-Husseini AE, Leavitt BR, Hayden MR. Als2-deficient mice exhibit disturbances in endosome trafficking associated with motor behavioral abnormalities. Proc Natl Acad Sci USA. 2006;103:9595-9600. 
92. Panzeri C, De Palma C, Martinuzzi A, Daga A, De Polo G, Bresolin N, Miller CC, Tudor EL, Clementi E, Bassi MT. The first ALS2 missense mutation associated with JPLS reveals new aspects of alsin biological function. Brain. 2006;129:1710-1719.

93. Rismanchi N, Soderblom C, Stadler J, Zhu PP, Blackstone C. Atlastin GTPases are required for Golgi apparatus and ER morphogenesis. Hum Mol Genet. 2008;17:15911604.

94. Orso G, Pendin D, Liu S, Tosetto J, Moss TJ, Faust JE, Micaroni M, Egorova A, Martinuzzi A, McNew JA, Daga A. Homotypic fusion of ER membranes requires the dynamin-like GTPase atlastin. Nature. 2009;460:978-983.

95. Hu J, Shibata Y, Voss C, Shemesh T, Li Z, Coughlin M, Kozlov MM, Rapoport TA, Prinz WA. Membrane proteins of the endoplasmic reticulum induce high-curvature tubules. Science. 2008;319:1247-1250.

96. Evans K, Keller C, Pavur K, Glasgow K, Conn B, Lauring B. Interaction of two hereditary spastic paraplegia gene products, spastin and atlastin, suggests a common pathway for axonal maintenance. Proc Natl Acad Sci USA. 2006;103(28):10666-10671.

97. Park SH, Zhu PP, Parker RL, Blackstone C. Hereditary spastic paraplegia proteins REEP1, spastin, and atlastin-1 coordinate microtubule interactions with the tubular ER network. J Clin Invest. 2010;120(4):1097-1110.

98. Schlaitz AL, Thompson J, Wong CCL, Yates JR 3rd, Heald R. REEP3/4 ensure endoplasmic reticulum clearance from metaphase chromatin and proper nuclear envelope architecture. Dev Cell. 2013;26:315-323.

99. O'Sullivan NC, Jahn TR, Reid E and O'Kane CJ. Reticulon-like-1, the Drosophila orthologue of the hereditary spastic paraplegia gene reticulon 2 , is required for organization of endoplasmic reticulum and of distal motor axons. Hum Mol Genet. 2012;21:3356-3365. 
100. *Yalçın B, Zhao L, Stofanko M, O'Sullivan NC, Kang ZH, Roost A, Thomas MR, Zaessinger S, Blard O, Patto AL, Sohail A, Baena V, Terasaki M, O'Kane CJ. Modeling of axonal endoplasmic reticulum network by spastic paraplegia proteins. Elife. 2017;6. The authors investigated the interplay between reticulon and REEP proteins in axonal ER organization in Drosophila models.

101. *Allison R, Edgar JR, Pearson G, Rizo T, Newton T, Günther S, Berner F, Hague J, Connell JW, Winkler J, Lippincott-Schwartz J, Beetz C, Winner B, Reid E. Defects in ER-endosome contacts impact lysosome function in hereditary spastic paraplegia. J Cell Biol. 2017;216:1337-1355. This study shows that defects in ER-endosome contacts are responsible for lysosome dysfunctions in several models of HSP. The authors proposed this as a unifying model of axonal degeneration.

102. Welte MA. Expanding roles for lipid droplets. Curr Biol. 2015;25:R470-R481.

103. Falk J, Rohde M, Bekhite MM et al.: Functional mutation analysis provides evidence for a role of REEP1 in lipid droplet biology. Hum Mutat. 2014;35:497-504.

104. Klemm RW, Norton JP, Cole RA, Li CS, Park SH, Crane MM, Li L, Jin D, Boye-Doe A, Liu TY, Shibata Y, Lu H, Rapoport TA, Farese RV Jr, Blackstone C, Guo Y, Mak HY. A conserved role for atlastin GTPases in regulating lipid droplet size. Cell Rep. $2013 ; 3: 1465-1475$.

105. **Papadopoulos C, Orso G, Mancuso G, Herholz M, Gumeni S, Tadepalle N, Jüngst C, Tzschichholz A, Schauss A, Höning S, Trifunovic A, Daga A, Rugarli EI: Spastin binds to lipid droplets and affects lipid metabolism. PLoS Genet. 2015;11:e1005149.

Functional studies revealing an unexpected involvement of spastin, the gene product most often affected in HSP, in lipid droplet formation in a Drosophila model of SPG4. 
106. Renvoisé B, Malone B, Falgairolle M, Munasinghe J, Stadler J, Sibilla C, Park SH, Blackstone C. Reep1 null mice reveal a converging role for hereditary spastic paraplegia proteins in lipid droplet regulation. Hum Mol Genet. 2016;25:5111-5125.

107. Inloes JM, Hsu KL, Dix MM, Viader A, Masuda K, Takei T, Wood MR, Cravatt BF. The hereditary spastic paraplegia-related enzyme DDHD2 is a principal brain triglyceride lipase. Proc Natl Acad Sci USA. 2014;111:14924-14929.

108. Renvoisé B, Stadler J, Singh R, Bakowska JC, Blackstone C. Spg20-/- mice reveal multimodal functions for Troyer syndrome protein spartin in lipid droplet maintenance, cytokinesis and BMP signaling. Hum Mol Genet. 2012;21:3604-3618.

109. Boukhris A, Schule R, Loureiro JL, Lourenço CM, Mundwiller E, Gonzalez MA, Charles P, Gauthier J, Rekik I, Acosta Lebrigio RF, Gaussen M, Speziani F, Ferbert A, Feki I, Caballero-Oteyza A, Dionne-Laporte A, Amri M, Noreau A, Forlani S, Cruz VT, Mochel F, Coutinho P, Dion P, Mhiri C, Schols L, Pouget J, Darios F, Rouleau GA, Marques W Jr, Brice A, Durr A, Zuchner S, Stevanin G. Alteration of ganglioside biosynthesis responsible for complex hereditary spastic paraplegia. Am J Hum Genet. 2013;93:118-123.

110. Harlalka GV, Lehman A, Chioza B, Baple EL, Maroofian R, Cross H, Sreekantan-Nair A, Priestman DA, Al-Turki S, McEntagart ME, Proukakis C, Royle L, Kozak RP, Bastaki L, Patton M, Wagner K, Coblentz R, Price J, Mezei M, Schlade-Bartusiak K, Platt FM, Hurles ME, Crosby AH. Mutations in B4GALNT1 (GM2 synthase) underlie a new disorder of ganglioside biosynthesis. Brain. 2013;136:3618-3624.

111. Raju D, Schonauer S, Hamzeh H, Flynn KC, Bradke F, Vom Dorp K, Dörmann P, Yildiz Y, Trötschel C, Poetsch A, Breiden B, Sandhoff K, Körschen HG, Wachten D. Accumulation of glucosylceramide in the absence of the beta-glucosidase GBA2 alters cytoskeletal dynamics. PLoS Genet. 2015;11(3):e1005063. 
112. Schüle R, Siddique T, Deng HX, Yang Y, Donkervoort S, Hansson M, Madrid RE, Siddique N, Schöls L, Björkhem I. Marked accumulation of 27-hydroxycholesterol in SPG5 patients with hereditary spastic paresis. J Lipid Res. 2010;51:819-823.

113. Vitner EB, Platt FM, Futerman AH. Common and uncommon pathogenic cascades in lysosomal storage diseases. J Biol Chem. 2010;285:20423-20427.

114. Ferreira CR, Gahl WA. Lysosomal storage diseases. Transl Sci Rare Dis. 2017;2:1-71.

115. Hirst J, Edgar JR, Esteves T et al.: Loss of AP-5 results in accumulation of aberrant endolysosomes: defining a new type of lysosomal storage disease. Hum Mol Genet. $2015 ; 24: 4984-4996$.

116. Chang J, Lee S, Blackstone C. Spastic paraplegia proteins spastizin and spatacsin mediate autophagic lysosome reformation. J Clin Invest. 2014;124:5249-5262.

117. Khundadze M, Kollmann K, Koch N, Biskup C, Nietzsche S, Zimmer G, Hennings JC, Huebner AK, Symmank J, Jahic A, Ilina EI, Karle K, Schöls L, Kessels M, Braulke T, Qualmann B, Kurth I, Beetz 6, Hübner CA. A hereditary spastic paraplegia mouse model supports a role of ZFYVE26/SPASTIZIN for the endolysosomal system. PLoS Genetics. 2013;9:e1003988.

118. Varga RE, Khundadze M, Damme M, Nietzsche S, Hoffmann B, Stauber T, Koch N, Hennings JC, Franzka P, Huebner AK, Kessels MM, Biskup C, Jentsch TJ, Qualmann B, Braulke T, Kurth I, Beetz C, Hübner CA. In vivo evidence for lysosome depletion and impaired autophagic clearance in hereditary spastic paraplegia type SPG11. PLoS Genet. 2015;11:e1005454.

119. Branchu J, Boutry M, Sourd L, Depp M, Leone C, Corriger A, Vallucci M, Esteves T, Matusiak R, Dumont M, Muriel MP, Santorelli FM, Brice A, El Hachimi KH, Stevanin G, Darios F. Loss of spatacsin function alters lysosomal lipid clearance leading to upper and lower motor neuron degeneration. Neurobiol Dis. 2017;102:21-37. 
120. ** Boutry M, Branchu J, Lustremant C, Pujol C, Pernelle J, Matusiak R, Seyer A, Poirel M, Chu-Van E, Pierga A, Dobrenis K, Puech JP, Caillaud C, Durr A, Brice A, Colsch B, Mochel F, El Hachimi KH, Stevanin G, Darios F. Inhibition of lysosome membrane recycling causes accumulation of gangliosides that contribute to neurodegeneration. Cell Rep. 2018;23:3813-3826. This study shows that spatacsin is important for lysosome membrane recycling and ganglioside clearance. The accumulation of gangliosides in lysosomes in SPG11 models is deleterious to neurons and its prevention decreases cell death rates in vitro and improves motor phenotype in zebrafish models.

121. Onyenwoke RU, Brenman JE. Lysosomal storage diseases-regulating neurodegeneration. J Exp Neurosci. 2015;9:81-91.

122. Yang DS, Stavrides P, Saito M, Kumar A, Rodriguez-Navarro JA, Pawlik M, Huo C, Walkley SU, Saito M, Cuervo AM, Nixon RA. Defective macroautophagic turnover of brain lipids in the TgCRND8 Alzheimer mouse model: prevention by correcting lysosomal proteolytic deficits. Brain. 2014;137:3300-3318.

123. Bross P, Naundrup S, Hansen J, Nielsen MN, Christensen JH, Kruhøffer M, Palmfeldt J, Corydon TJ, Gregersen N, Ang D, Georgopoulos C, Nielsen KL. The Hsp60-(p.V98I) mutation associated with hereditary spastic paraplegia SPG13 compromises chaperonin function both in vitro and in vivo. J Biol Chem. 2008;283:15694-15700.

124. Ferreirinha F, Quattrini A, Pirozzi M, Valsecchi V, Dina G, Broccoli V, Auricchio A, Piemonte F, Tozzi G, Gaeta L, Casari G, Ballabio A, Rugarli EI. Axonal degeneration in paraplegin-deficient mice is associated with abnormal mitochondria and impairment of axonal transport. J Clin Invest. 2004;113:231-242.

125. Lu J, Rashid F, Byrne PC. The hereditary spastic paraplegia protein spartin localises to mitochondria. J Neurochem. 2006;98:1908-1919. 
126. Yang Y, Liu W, Fang Z, Shi J, Che F, He C, Yao L, Wang E, Wu Y. A newly identified missense mutation in FARS2 causes autosomal-recessive spastic paraplegia. Hum Mutat. 2016;37:165-169.

127. *Lavie J, Serrat R, Bellance N, Courtand G, Dupuy JW, Tesson C, Coupry I, Brice A, Lacombe D, Durr A, Stevanin G, Darios F, Rossignol R, Goizet C, Bénard G. Mitochondrial morphology and cellular distribution are altered in SPG31 patients and are linked to DRP1 hyperphosphorylation. Hum Mol Genet. 2017;26(4):674-685. The authors report a secondary mitochondrial alteration in the cells of patients with REEP1 mutations, due to abnormal interactions between REEP1 and a mitochondrial protein.

128. Fransen E, D'Hooge R, Van Camp G, Verhoye M, Sijbers J, Reyniers E, Soriano P, Kamiguchi H, Willemsen R, Koekkoek SK, De Zeeuw CI, De Deyn PP, Van der Linden A, Lemmon V, Kooy RF, Willems PJ. L1 knockout mice show dilated ventricles, vermis hypoplasia and impaired exploration patterns. Hum Mol Genet. 1998;7(6):9991009.

129. Groh J, Friedman HC, Orel N, Ip CW, Fischer S, Spahn I, Schäffner E, Hörner M, Stadler D, Buttmann M, Varallyay C, Solymosi L, Sendtner M, Peterson AC, Martini R. Pathogenic inflammation in the CNS of mice carrying human PLP1 mutations. Hum Mol Genet. 2016;25(21):4686-4702.

130. **Fassier C, Hutt JA, Scholpp S, Lumsden A, Giros B, Nothias F, Schneider-Maunoury S, Houart C, Hazan J. Zebrafish atlastin controls motility and spinal motor axon architecture via inhibition of the BMP pathway. Nat Neurosci. 2010;13(11):1380-1387. Atlastin regulates BMP receptor trafficking and the inhibition of BMP signaling rescues motor defects and spinal motor axon abnormalities in zebrafish mimicking SPG3. 
131. Martin E, Yanicostas C, Rastetter A, Alavi-Naini SM, Maouedj A, Kabashi E, RivaudPechoux S, Brice A, Stevanin G, Soussi-Yanicostas N. Spatacsin and spastizin act in the same pathway required for proper spinal motor neuron axon outgrowth in zebrafish. Neurobiol Dis. 2012;48:299-308.

132. Fan Y, Wali G, Sutharsan R, Bellette B, Crane DI, Sue CM, Mackay-Sim A. Low dose tubulin-binding drugs rescue peroxisome trafficking deficit in patient-derived stem cells in hereditary spastic paraplegia. Biol Open. 2014;3(6):494-502.

133. *Julien C, Lissouba A, Madabattula S, Fardghassemi Y, Rosenfelt C, Androschuk A, Strautman J, Wong C, Bysice A, O'sullivan J, Rouleau GA, Drapeau P, Parker JA, Bolduc FV. Conserved pharmacological rescue of hereditary spastic paraplegia-related phenotypes across model organisms. Hum Mol Genet. 2016;25(6):1088-1099. The screening of chemical compounds modulating ER stress in various models of SPG4 identified molecules that attenuated locomotor defects.

134. Orso G, Martinuzzi A, Rossetto MG, Sartori E, Feany M, Daga A. Disease-related phenotypes in a Drosophila model of hereditary spastic paraplegia are ameliorated by treatment with vinblastine. J Clin Invest. 2005;115:3026-3034.

135. Pirozzi M, Quattrini A, Andolfi G, Dina G, Malaguti MC, Auricchio A, Rugarli EI. Intramuscular viral delivery of paraplegin rescues peripheral axonopathy in a model of hereditary spastic paraplegia. J Clin Invest. 2006;116:202-208.

136. Zhu PP, Denton KR, Pierson TM, Li XJ, Blackstone C. Pharmacologic rescue of axon growth defects in a human iPSC model of hereditary spastic paraplegia SPG3A. Hum Mol Genet. 2014;23(21):5638-5648.

137. **Schöls L, Rattay TW, Martus P, Meisner C, Baets J, Fischer I, Jägle C, Fraidakis MJ, Martinuzzi A, Saute JA, Scarlato M, Antenora A, Stendel C, Höflinger P, Lourenco CM, Abreu L, Smets K, Paucar M, Deconinck T, Bis DM, Wiethoff S, Bauer P, Arnoldi A, 
Marques W, Jardim LB, Hauser S, Criscuolo C, Filla A, Züchner S, Bassi MT, Klopstock T, De Jonghe P, Björkhem I, Schüle R. Hereditary spastic paraplegia type 5: natural history, biomarkers and a randomized controlled trial. Brain. 2017;140(12):3112-3127. The authors demonstrate a correlation between serum and CSF oxysterol concentrations in SPG5 patients. The use of atorvastatin reduced oxysterols in serum but not in CSF, whereas the placebo had no effect.

138. *Marelli C, Lamari F, Rainteau D, Lafourcade A, Banneau G, Humbert L, Monin ML, Petit E, Debs R, Castelnovo G, Ollagnon E, Lavie J, Pilliod J, Coupry I, Babin PJ, Guissart C, Benyounes I, Ullmann U, Lesca G, Thauvin-Robinet C, Labauge P, Odent S, Ewenczyk C, Wolf C, Stevanin G, Hajage D, Durr A, Goizet C, Mochel F. Plasma oxysterols: biomarkers for diagnosis and treatment in spastic paraplegia type 5. Brain. 2018;141:72-84. A phase II clinical trial in 12 patients showed that the combination of atorvastatin and chenodeoxycholic acid lowered plasma oxysterol concentration and improved bile-acid profile in SPG5 patients. 


\section{Figure Legend}

Figure 1: Overview of the main altered/known functions of proteins involved in HSP. ER: endoplasmic reticulum 


\section{Cytoskeleton-dependent movement}

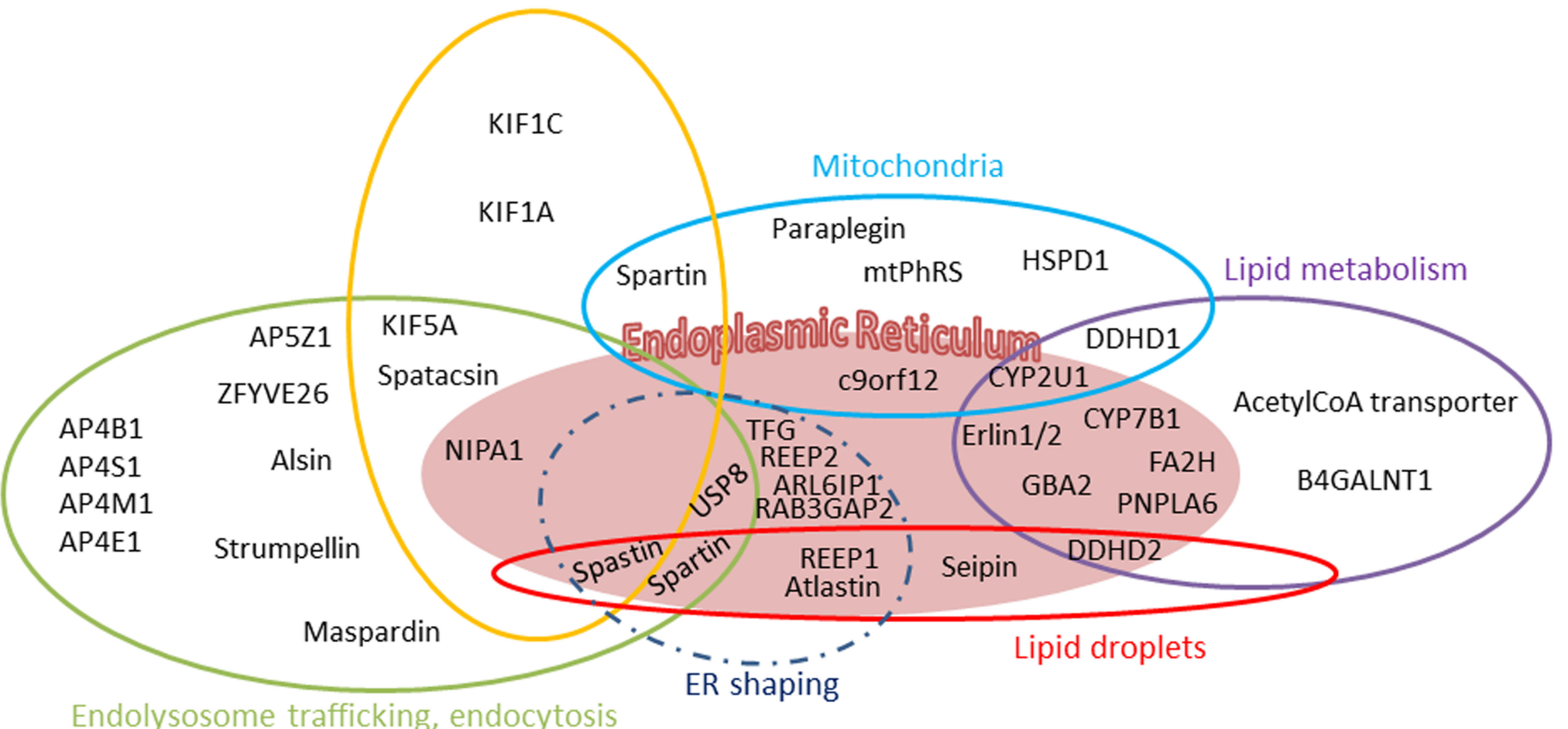

Endolysosome trafficking, endocytosis

$$
\text { ER shaping }
$$


Table 1. Loci and genes implicated in spastic paraplegias, the proteins they encode and the associated clinical features in patients

ARHSP - autosomal recessive hereditary spastic paraplegia; ATPase-adenosine triphosphatase; CMT 4D-Charcot-Marie-Tooth subtype 4D; ERendoplasmic reticulum; FR-frameshift; GTPase-guanosine triphosphatase; IFD-in-frame deletion or duplication; LL-lower limbs; MIM-Mendelian inheritance in man; MS-missense; NS-nonsense; RG-rearrangements; SPG-spastic gait gene; SPL-splice site mutations; TCC - thin corpus callosum; UL-upper limbs; UTR-untranslated region; $\mathrm{WMH}$ - white matter hyperintensities.

\begin{tabular}{|c|c|c|c|c|c|c|c|}
\hline $\begin{array}{l}\text { Locus } \\
\text { (MIM) }\end{array}$ & Chromosome & $\begin{array}{l}\text { Gene } \\
\text { (protein) }\end{array}$ & Putative roles of the protein & Mutations & Frequency & $\begin{array}{l}\text { Age at } \\
\text { onset, } y\end{array}$ & Phenotype in patients \\
\hline \multicolumn{8}{|c|}{ Autosomal dominant forms } \\
\hline $\begin{array}{l}\text { SPG4 } \\
(182601)\end{array}$ & $2 p 22.3$ & $\begin{array}{l}\text { SPAST } \\
\text { (spastin) }\end{array}$ & $\begin{array}{l}\text { Microtubule-severing activity, } \\
\text { early secretory pathway, BMP } \\
\text { signaling }\end{array}$ & $\begin{array}{l}\text { MS, NS, FR, } \\
\text { SPL, RG }\end{array}$ & $\begin{array}{l}40 \% \text { of } \\
\text { dominant } \\
\text { forms }(9 \%- \\
18 \% \text { of } \\
\text { sporadic } \\
\text { cases) }\end{array}$ & $\begin{array}{l}\text { Variable }(0- \\
74)\end{array}$ & $\begin{array}{l}\text { Pure, but sometimes cognitive deficits, } \\
\text { with incomplete penetrance }\end{array}$ \\
\hline $\begin{array}{l}\text { SPG6 } \\
(600363)\end{array}$ & $15 q 11.1$ & NIPA1 & $\begin{array}{l}\mathrm{Mg}^{2+} \text { transporter, endosomal } \\
\text { trafficking, BMP signaling }\end{array}$ & $\begin{array}{l}\text { MS (hot spot } \\
\text { at c.316) }\end{array}$ & Rare & $8-40$ & $\begin{array}{l}\text { Pure or rarely with seizures, memory } \\
\text { impairment or neuropathy }\end{array}$ \\
\hline $\begin{array}{l}\text { SPG8 } \\
(603563)\end{array}$ & $8 q 24.13$ & $\begin{array}{l}\text { WASHC5 } \\
\text { (strumpellin) }\end{array}$ & Endosomal trafficking & MS, RG & Rare & $18-60$ & Pure or atrophy of shins \\
\hline $\begin{array}{l}\text { SPG10 } \\
(604187)\end{array}$ & $12 q 13$ & KIF5A & Motor protein (axonal transport) & $\begin{array}{l}\text { MS, NS, } \\
\text { IFD, SPL }\end{array}$ & $3 \%$ & $2-51$ & $\begin{array}{l}\text { Pure or neuropathy, amyotrophy, } \\
\text { parkinsonism }\end{array}$ \\
\hline $\begin{array}{l}\text { SPG12 } \\
(604805)\end{array}$ & $19 q 13.32$ & $\begin{array}{l}\text { RTN2 } \\
\text { (Reticulon 2) }\end{array}$ & ER-shaping protein & $\mathrm{FR}, \mathrm{RG}$ & Rare & $5-36$ & Pure \\
\hline $\begin{array}{l}\text { SPG13 } \\
(605280)\end{array}$ & $2 q 33.1$ & HSPD1 & Mitochondrial chaperone & MS & 2 families & $17-68$ & Pure \\
\hline $\begin{array}{l}\text { SPG17 } \\
(270685)\end{array}$ & $11 q 13$ & $\begin{array}{l}\text { BSCL2 } \\
\text { (seipin) }\end{array}$ & ER protein, lipid metabolism & MS & Rare & $8-40$ & Silver syndrome: severe distal wasting \\
\hline
\end{tabular}




\begin{tabular}{|c|c|c|c|c|c|c|c|}
\hline $\begin{array}{l}\text { SPG19 } \\
(607152)\end{array}$ & $9 q 33-q 34$ & Unknown & - & - & 1 family & $36-55$ & Pure \\
\hline $\begin{array}{l}\text { SPG29 } \\
(609727)\end{array}$ & 1p31.1-p21.1 & Unknown & - & - & 1 family & $\begin{array}{l}\text { Childhood } \\
\text { through } \\
\text { early } \\
\text { adulthood }\end{array}$ & $\begin{array}{l}\text { Sensorineural hearing impairment, } \\
\text { neonatal hyperbilirubinemia without } \\
\text { kernicterus, hiatal hernia }\end{array}$ \\
\hline $\begin{array}{l}\text { SPG31 } \\
(610250)\end{array}$ & $2 \mathrm{p} 11.2$ & REEP1 & $\begin{array}{l}\text { ER-shaping protein, ER- } \\
\text { microtubule interaction, } \\
\text { mitochondrial function }\end{array}$ & $\begin{array}{l}\text { MS, NS, FR, } \\
\text { SPL, 3' UTR }\end{array}$ & $4.5 \%$ & Variable & $\begin{array}{l}\text { Pure or with amyotrophy, distal } \\
\text { sensory loss }\end{array}$ \\
\hline $\begin{array}{l}\text { SPG36 } \\
(613096)\end{array}$ & $12 q 23-q 24$ & Unknown & - & - & 1 family & $14-33$ & $\begin{array}{l}\text { Demyelinating sensorimotor } \\
\text { neuropathy }\end{array}$ \\
\hline $\begin{array}{l}\text { SPG38 } \\
(612335)\end{array}$ & 4p16-p15 & Unknown & - & - & 1 family & $16-19$ & Amyotrophy \\
\hline $\begin{array}{l}\text { SPG41 } \\
(613364)\end{array}$ & $11 \mathrm{p} 14.1-\mathrm{p} 11.2$ & Unknown & - & - & 1 family & $\begin{array}{l}\text { mean } \\
16.6 \pm 3.0\end{array}$ & Pure \\
\hline $\begin{array}{l}\text { SPG42 } \\
(612539)\end{array}$ & $3 q 25.31$ & SLC33A1 & $\begin{array}{l}\text { ER membrane transporter, BMP } \\
\text { signaling, autophagy }\end{array}$ & MS & Rare & $4-42$ & Pure \\
\hline $\begin{array}{l}\text { SPG73 } \\
(616282)\end{array}$ & $19 q 13.33$ & CPT1C & Lipid metabolism & MS & 1 family & $19-48$ & $\begin{array}{l}\text { Muscle atrophy, Delayed central } \\
\text { sensory evoked potentials }\end{array}$ \\
\hline \multicolumn{8}{|c|}{ Autosomal recessive forms } \\
\hline $\begin{array}{l}\text { SPG5A } \\
(270800)\end{array}$ & $8 q 21.3$ & CYP7B1 & $\begin{array}{l}\text { Cholesterol and neurosteroid } \\
\text { metabolism }\end{array}$ & $\begin{array}{l}\text { MS, NS, } \\
\text { SPL and FR }\end{array}$ & $7 \%$ & $1-47$ & $\begin{array}{l}\text { Pure or with cerebellar signs, } \\
\text { cognitive impairment, nystagmus }\end{array}$ \\
\hline $\begin{array}{l}\text { SPG11 } \\
(604360)\end{array}$ & $15 q 21.1$ & $\begin{array}{l}\text { SPG11 } \\
\text { (spatacsin) }\end{array}$ & Lysosome shaping, autophagy & $\begin{array}{l}\text { NS, MS, FR, } \\
\text { SPL, IFD, } \\
\text { RG }\end{array}$ & $\begin{array}{l}21 \%(59 \% \\
\text { of ARHSP- } \\
\text { TCC) }\end{array}$ & $\begin{array}{l}\text { Childhood } \\
\text { through } \\
\text { adulthood }\end{array}$ & $\begin{array}{l}\text { Pure or mostly complex with cognitive } \\
\text { impairment, TCC, neuropathy, } \\
\text { amyotrophy, WMH, mild cerebellar } \\
\text { signs, cerebral atrophy }\end{array}$ \\
\hline $\begin{array}{l}\text { SPG14 } \\
(605229)\end{array}$ & $3 q 27-q 28$ & Unknown & - & - & 1 family & Adulthood & $\begin{array}{l}\text { Distal motor neuropathy, cognitive } \\
\text { impairment, visual agnosia }\end{array}$ \\
\hline $\begin{array}{l}\text { SPG15 } \\
(270700)\end{array}$ & $14 q 24.1$ & $\begin{array}{l}\text { ZFYVE26 } \\
\text { (spastizin) }\end{array}$ & $\begin{array}{l}\text { Endosomal trafficking, } \\
\text { autophagy, cytokinesis }\end{array}$ & $\begin{array}{l}\text { NS, MS, FR, } \\
\text { SPL, RG }\end{array}$ & $4 \%$ & $5-23$ & $\begin{array}{l}\text { Pure or mostly complex with cognitive } \\
\text { impairment, cerebellar signs, TCC, } \\
\text { WMH, neuropathy, amyotrophy, } \\
\text { retinopathy (Kjellin syndrome) }\end{array}$ \\
\hline
\end{tabular}




\begin{tabular}{|c|c|c|c|c|c|c|c|}
\hline $\begin{array}{l}\text { SPG20 } \\
(275900)\end{array}$ & $13 q 12.3$ & $\begin{array}{l}\text { SPART } \\
\text { (spartin) }\end{array}$ & $\begin{array}{l}\text { Endosomal trafficking, } \\
\text { microtubule interaction, lipid } \\
\text { droplet turnover, BMP signaling, } \\
\text { mitochondrial function }\end{array}$ & $\begin{array}{l}\text { MS, SPL, } \\
\text { FR }\end{array}$ & Rare & $\begin{array}{l}\text { Early } \\
\text { childhood }\end{array}$ & $\begin{array}{l}\text { Troyer syndrome: developmental } \\
\text { delay and short stature, cognitive } \\
\text { impairment, cerebellar signs, distal } \\
\text { amyotrophy }\end{array}$ \\
\hline $\begin{array}{l}\text { SPG21 } \\
(248900)\end{array}$ & $15 q 22.31$ & $\begin{array}{l}\text { SPG21 } \\
\text { (maspardin) }\end{array}$ & $\begin{array}{l}\text { Endosomal/trans-Golgi } \\
\text { trafficking }\end{array}$ & MS, FR & Rare & $20-60$ & $\begin{array}{l}\text { Cognitive decline and apraxia } \\
\text { (Japanese family) or Mast syndrome: } \\
\text { cognitive decline, extrapyramidal } \\
\text { syndrome, dementia, dysarthria, TCC, } \\
\text { WMH, cerebellar signs, neuropathy. }\end{array}$ \\
\hline $\begin{array}{l}\text { SPG23 } \\
(270750)\end{array}$ & $1 q 32.1$ & DSTYK & $\begin{array}{l}\text { Dual serine/threonine and } \\
\text { tyrosine protein kinase }\end{array}$ & RG & 3 families & Childhood & $\begin{array}{l}\text { Lison syndrome: pigmentary } \\
\text { abnormalities, cognitive impairment, } \\
\text { peripheral neuropathy }\end{array}$ \\
\hline $\begin{array}{l}\text { SPG24 } \\
(607584)\end{array}$ & $13 q 14$ & Unknown & - & - & 1 family & $\begin{array}{l}\text { Early } \\
\text { childhood }\end{array}$ & Pure \\
\hline $\begin{array}{l}\text { SPG25 } \\
(608220)\end{array}$ & $6 q 23-24.1$ & Unknown & - & - & 1 family & $30-46$ & $\begin{array}{l}\text { Mild sensorimotor neuropathy, spinal } \\
\text { disc herniation, spondylosis }\end{array}$ \\
\hline $\begin{array}{l}\text { SPG26 } \\
(609195)\end{array}$ & $12 \mathrm{p} 13.3$ & B4GALNT1 & $\begin{array}{l}\text { Biosynthesis of complex } \\
\text { gangliosides }\end{array}$ & $\begin{array}{l}\text { MS, NS, } \\
\text { SPL, IFD, } \\
\text { FR }\end{array}$ & Rare & $\begin{array}{l}\text { First or } \\
\text { second } \\
\text { decades of } \\
\text { life }\end{array}$ & $\begin{array}{l}\text { Cognitive impairment, distal } \\
\text { amyotrophy, dysarthria, cerebellar } \\
\text { signs, cortical atrophy, ataxia, } \\
\text { neuropathy, cataracts }\end{array}$ \\
\hline $\begin{array}{l}\text { SPG27 } \\
(609041)\end{array}$ & $10 \mathrm{q} 22.1-\mathrm{q} 24.1$ & Unknown & - & - & 2 families & $\begin{array}{l}25-45(P) \\
2-7(C)\end{array}$ & $\begin{array}{l}\text { Pure or with sensorimotor } \\
\text { polyneuropathy, } 1 \text { case with cognitive } \\
\text { impairment and skeletal abnormalities }\end{array}$ \\
\hline $\begin{array}{l}\text { SPG28 } \\
(609340)\end{array}$ & $14 q 22.1$ & $D D H D 1$ & $\begin{array}{l}\text { Lipid metabolism, mitochondrial } \\
\text { function }\end{array}$ & NS, SPL, FR & Rare & $6-16$ & $\begin{array}{l}\text { Pure or with distal sensory } \\
\text { impairment, neuropathy or oculomotor } \\
\text { disturbances }\end{array}$ \\
\hline $\begin{array}{l}\text { SPG32 } \\
(611252)\end{array}$ & $14 q 12-q 21$ & Unknown & - & - & 1 family & Childhood & $\begin{array}{l}\text { Cognitive impairment, TCC, cortical } \\
\text { and cerebellar atrophy, pontine } \\
\text { dysraphia }\end{array}$ \\
\hline $\begin{array}{l}\text { SPG35 } \\
(612319)\end{array}$ & $16 q 23.1$ & $\mathrm{FA} 2 \mathrm{H}$ & $\begin{array}{l}\text { Myelination, fatty acid } \\
\text { metabolism }\end{array}$ & $\begin{array}{l}\text { MS,NS, } \\
\text { SPL, FR }\end{array}$ & Rare & $\begin{array}{l}2-17,1 \\
\text { family with } \\
\text { adult onset }\end{array}$ & $\begin{array}{l}\text { Spastic quadriparesis, cognitive } \\
\text { impairment, ataxia, optic atrophy, } \\
\text { seizures, TCC, cerebellar atrophy, } \\
\text { leukodystrophy, WMH }\end{array}$ \\
\hline
\end{tabular}




\begin{tabular}{|c|c|c|c|c|c|c|c|}
\hline $\begin{array}{l}\text { SPG39 } \\
(612020)\end{array}$ & $19 p 13.2$ & PNPLA6 & $\begin{array}{l}\text { Lipid metabolism, axonal } \\
\text { integrity }\end{array}$ & MS, FR, RG & Rare & Variable & $\begin{array}{l}\text { Distal muscle atrophy, axonal motor } \\
\text { neuropathy }\end{array}$ \\
\hline $\begin{array}{l}\text { SPG43 } \\
(615043)\end{array}$ & $19 q 12$ & C19orf12 & Unknown & MS & 3 families & Childhood & $\begin{array}{l}\text { Distal muscle atrophy, distal sensory } \\
\text { impairment, motor neuropathy }\end{array}$ \\
\hline $\begin{array}{l}\text { SPG44 } \\
(613206)\end{array}$ & $1 q 42.13$ & GJC2 & $\begin{array}{l}\text { Myelination, oligodendrocyte } \\
\text { homeostasis }\end{array}$ & MS, FR & 1 family & $\begin{array}{l}\text { First or } \\
\text { second } \\
\text { decades of } \\
\text { life }\end{array}$ & $\begin{array}{l}\text { Cerebellar ataxia, dysarthria, cognitive } \\
\text { impairment, TCC }\end{array}$ \\
\hline $\begin{array}{l}\text { SPG45/ } \\
\text { SPG65 } \\
(613162)\end{array}$ & $10 q 24.33$ & NT5C2 & $\begin{array}{l}\text { Purine/pyrimidine nucleotide } \\
\text { metabolism }\end{array}$ & $\begin{array}{l}\text { MS, NS, } \\
\text { SPL, FR, } \\
\text { RG }\end{array}$ & Rare & Infancy & $\begin{array}{l}\text { Cognitive impairment, delayed motor } \\
\text { development TCC, WMH }\end{array}$ \\
\hline $\begin{array}{l}\text { SPG46 } \\
(614409)\end{array}$ & $9 p 13.3$ & GBA2 & Lipid metabolism & $\begin{array}{l}\text { MS, NS, } \\
\text { SPL, FR }\end{array}$ & Rare & $1-16$ & $\begin{array}{l}\text { Cognitive impairment, cerebellar } \\
\text { ataxia, dysarthria, nystagmus, male } \\
\text { infertility, cerebral and cerebellar } \\
\text { atrophy, TCC, polyneuropathy }\end{array}$ \\
\hline $\begin{array}{l}\text { SPG47 } \\
(614066)\end{array}$ & $1 \mathrm{p} 13.2$ & AP4B1 & Vesicle formation and trafficking & FR & Rare & Birth & $\begin{array}{l}\text { Severe cognitive impairment, } \\
\text { microcephaly, seizures, dystonia, } \\
\text { dysarthria, TCC, WMH }\end{array}$ \\
\hline $\begin{array}{l}\text { SPG48 } \\
(613647)\end{array}$ & $7 p 22.1$ & AP5Z1 & $\begin{array}{l}\text { Vesicle trafficking, endosomal } \\
\text { dynamics, DNA repair }\end{array}$ & MS, NS, FR & Rare & $\begin{array}{l}\text { Mostly } \\
\text { adult-onset } \\
(2-60)\end{array}$ & $\begin{array}{l}\text { Cognitive impairment, ataxia, } \\
\text { parkinsonism, neuropathy, TCC, } \\
\text { WMH }\end{array}$ \\
\hline $\begin{array}{l}\text { SPG49 } \\
(615031)\end{array}$ & $14 q 32.31$ & TECPR2 & Autophagy & $\mathrm{FR}$ & Rare & Infancy & $\begin{array}{l}\text { Hypotonia, microcephaly, ataxia, } \\
\text { dysarthria, areflexia, intellectual } \\
\text { disability, cerebral atrophy, TCC, } \\
\text { breathing abnormalities }\end{array}$ \\
\hline $\begin{array}{l}\text { SPG50 } \\
(612936)\end{array}$ & $7 q 22.1$ & AP4M1 & Vesicle formation and trafficking & MS, NS, FR & Rare & Birth & $\begin{array}{l}\text { Severe cognitive impairment, } \\
\text { microcephaly, seizures, cerebellar } \\
\text { atrophy, strabismus, TCC, WMH }\end{array}$ \\
\hline $\begin{array}{l}\text { SPG51 } \\
(613744)\end{array}$ & $15 q 21.2$ & AP4E1 & Vesicle formation and trafficking & NS, FR, RG & Rare & Birth & $\begin{array}{l}\text { Severe cognitive impairment, } \\
\text { microcephaly, seizures, cortical and } \\
\text { cerebellar atrophy, hypotonia, } \\
\text { nystagmus }\end{array}$ \\
\hline $\begin{array}{l}\text { SPG52 } \\
(614067)\end{array}$ & $14 q 12$ & AP4S1 & Vesicle formation and trafficking & NS, FR & Rare & Birth & $\begin{array}{l}\text { Severe cognitive impairment, } \\
\text { microcephaly, axial hypotonia, TCC }\end{array}$ \\
\hline
\end{tabular}




\begin{tabular}{|c|c|c|c|c|c|c|c|}
\hline $\begin{array}{l}\text { SPG53 } \\
(614898)\end{array}$ & $8 p 22$ & VPS37A & Vesicle trafficking & MS & 2 families & Infancy & $\begin{array}{l}\text { Delayed psychomotor development, } \\
\text { cognitive impairment, kyphosis }\end{array}$ \\
\hline $\begin{array}{l}\text { SPG54 } \\
(615033)\end{array}$ & $8 p 11.23$ & DDHD2 & $\begin{array}{l}\text { Lipid metabolism, membrane } \\
\text { trafficking }\end{array}$ & $\begin{array}{l}\text { MS, NS, } \\
\text { SPL, FR, } \\
\text { RG }\end{array}$ & Rare & Infancy & $\begin{array}{l}\text { Cognitive impairment, developmental } \\
\text { delay, dysarthria, strabismus, TCC, } \\
\text { WMH }\end{array}$ \\
\hline $\begin{array}{l}\text { SPG55 } \\
(615035)\end{array}$ & $12 q 24.31$ & C12orf65 & Mitochondrial matrix protein & NS, SPL, FR & Rare & $\begin{array}{l}\text { First or } \\
\text { second } \\
\text { decades of } \\
\text { life }\end{array}$ & $\begin{array}{l}\text { Optic atrophy, strabismus, distal } \\
\text { muscle atrophy and weakness, } \\
\text { cognitive impairment, neuropathy }\end{array}$ \\
\hline $\begin{array}{l}\text { SPG56 } \\
(615030)\end{array}$ & $4 q 25$ & CYP2U1 & Lipid metabolism & $\begin{array}{l}\text { MS, NS, } \\
\text { SPL, FR }\end{array}$ & $1.5 \%$ & 0 (Birth) - 8 & $\begin{array}{l}\text { Pure or with delayed motor } \\
\text { development, axonal neuropathy, } \\
\text { dystonia, cognitive impairment, TCC } \\
\text { and WMH (rare) }\end{array}$ \\
\hline $\begin{array}{l}\text { SPG57 } \\
(615658)\end{array}$ & $3 q 12.2$ & TFG & $\begin{array}{l}\text { ER morphogenesis, vesicle } \\
\text { trafficking }\end{array}$ & MS & 5 families & Infancy & $\begin{array}{l}\text { Pure or with optic atrophy, axonal and } \\
\text { demyelinating sensorimotor } \\
\text { neuropathy }\end{array}$ \\
\hline $\begin{array}{l}\text { SPG58 } \\
(611302)\end{array}$ & $17 p 13.2$ & KIF1C & Motor protein (axonal transport) & $\begin{array}{l}\text { MS, NS, } \\
\text { SPL, RG }\end{array}$ & Rare & $2-30$ & $\begin{array}{l}\text { Pure or mostly complex with ataxia, } \\
\text { dysarthria, distal muscle atrophy, } \\
\text { cerebellar atrophy }\end{array}$ \\
\hline $\begin{array}{l}\text { SPG59 } \\
(603158)\end{array}$ & $15 q 21.2$ & USP8 & $\begin{array}{l}\text { Endosomal morphology, } \\
\text { membrane trafficking }\end{array}$ & MS & 1 family & 20 months & Nystagmus, borderline intelligence \\
\hline $\begin{array}{l}\text { SPG60 } \\
(612167)\end{array}$ & $3 p 22.2$ & WDR48 & $\begin{array}{l}\text { DNA damage repair, lysosomal } \\
\text { trafficking }\end{array}$ & FR & 1 family & 1 year & $\begin{array}{l}\text { Nystagmus, peripheral neuropathy, } \\
\text { mild learning disability }\end{array}$ \\
\hline $\begin{array}{l}\text { SPG61 } \\
(615685)\end{array}$ & $16 \mathrm{p} 12.3$ & ARL6IP1 & $\begin{array}{l}\text { ER morphogenesis, protein } \\
\text { transport }\end{array}$ & NS, FR & 3 families & $\begin{array}{l}\text { Birth to } \\
\text { infancy }\end{array}$ & $\begin{array}{l}\text { Sensorimotor neuropathy, } \\
\text { acromutilation, intellectual disability, } \\
\text { developmental delay, brain atrophy }\end{array}$ \\
\hline $\begin{array}{l}\text { SPG62 } \\
(615681)\end{array}$ & $10 q 24.31$ & ERLIN1 & $\begin{array}{l}\text { ER-associated degradation, } \\
\text { cholesterol homeostasis }\end{array}$ & MS, ND, IFD & 3 families & $1-13$ & Pure \\
\hline $\begin{array}{l}\text { SPG63 } \\
(615686)\end{array}$ & $1 \mathrm{p} 13.3$ & AMPD2 & Purine nucleotide metabolism & MS, FR & 2 families & Infancy & $\begin{array}{l}\text { Amyotrophy, short stature, TCC, } \\
\text { WMH }\end{array}$ \\
\hline $\begin{array}{l}\text { SPG64 } \\
(615683)\end{array}$ & $10 q 24.1$ & ENTPD1 & Purine nucleotide metabolism & MS, NS & 2 families & $3-22$ & $\begin{array}{l}\text { Dysarthria, cerebellar signs, } \\
\text { amyotrophy, intellectual disability, } \\
\text { delayed puberty, microcephaly, WMH }\end{array}$ \\
\hline
\end{tabular}




\begin{tabular}{|c|c|c|c|c|c|c|c|}
\hline $\begin{array}{l}\text { SPG66 } \\
(610009)\end{array}$ & $5 q 32$ & ARSI & $\begin{array}{l}\text { Hormone biosynthesis, cell } \\
\text { signaling }\end{array}$ & FR & 1 family & Infancy & $\begin{array}{l}\text { Amyotrophy, severe sensorimotor } \\
\text { polyneuropathy, corpus callosum and } \\
\text { cerebellar hypoplasia, colpocephaly }\end{array}$ \\
\hline $\begin{array}{l}\text { SPG67 } \\
(611655)\end{array}$ & $2 q 33.1$ & PGAP1 & $\begin{array}{l}\text { GPI biosynthesis, ER-to-Golgi } \\
\text { transport of GPI-anchor proteins }\end{array}$ & SPL & 1 family & Infancy & $\begin{array}{l}\text { Amyotrophy, cerebellar signs, corpus } \\
\text { callosum agenesis, vermis hypoplasia, } \\
\text { defective myelination }\end{array}$ \\
\hline $\begin{array}{l}\text { SPG68 } \\
(604806)\end{array}$ & $11 q 13.1$ & FLRT1 & $\begin{array}{l}\text { Cell adhesion, receptor } \\
\text { signaling }\end{array}$ & Nonstop & 1 family & Infancy & $\begin{array}{l}\text { Nystagmus, optic atrophy, } \\
\text { amyotrophy, peripheral neuropathy }\end{array}$ \\
\hline $\begin{array}{l}\text { SPG69 } \\
(609275)\end{array}$ & $1 q 41$ & RAB3GAP2 & $\begin{array}{l}\text { ER morphogenesis, exocytosis } \\
\text { of neurotransmitters and } \\
\text { hormones }\end{array}$ & NS & 1 family & Infancy & $\begin{array}{l}\text { Global developmental delay, } \\
\text { dysarthria, intellectual disability, } \\
\text { deafness, cataract }\end{array}$ \\
\hline $\begin{array}{l}\text { SPG70 } \\
(156560)\end{array}$ & $12 q 13.3$ & MARS & $\begin{array}{l}\text { Cytosolic methionyl-tRNA } \\
\text { synthetase }\end{array}$ & MS & 1 family & Infancy & $\begin{array}{l}\text { Amyotrophy, bilateral achilles } \\
\text { contracture }\end{array}$ \\
\hline $\begin{array}{l}\text { SPG71 } \\
(615635)\end{array}$ & $5 p 13.3$ & ZFR & Unknown & MS & 1 family & Infancy & TCC \\
\hline $\begin{array}{l}\text { SPG74 } \\
(616451)\end{array}$ & $1 q 42.13$ & IBA57 & Mitochondrial function & SPL & 1 family & First decade & $\begin{array}{l}\text { Optic atrophy, distal leg muscle } \\
\text { atrophy, axonal peripheral neuropathy }\end{array}$ \\
\hline $\begin{array}{l}\text { SPG75 } \\
(616680)\end{array}$ & $19 q 13.12$ & MAG & Myelination & MS & 2 families & $\begin{array}{l}\text { Early } \\
\text { childhood }\end{array}$ & $\begin{array}{l}\text { Optic atrophy, distal muscle atrophy, } \\
\text { cognitive impairment, peripheral } \\
\text { neuropathy, nystagmus, cerebellar } \\
\text { atrophy }\end{array}$ \\
\hline $\begin{array}{l}\text { SPG76 } \\
(616907)\end{array}$ & $11 q 13.1$ & CAPN1 & $\begin{array}{l}\text { Axon maturation and } \\
\text { maintenance }\end{array}$ & $\begin{array}{l}\text { MS, NS, } \\
\text { SPL, FR }\end{array}$ & 10 families & $\begin{array}{l}19-39,1 \\
\text { case with } \\
\text { congenital- } \\
\text { onset }\end{array}$ & $\begin{array}{l}\text { Pure or with dysarthria, ataxia, } \\
\text { sensory axonal neuropathy, } \\
\text { hyperreflexia }\end{array}$ \\
\hline $\begin{array}{l}\text { SPG77 } \\
(611592)\end{array}$ & $6 p 25.1$ & FARS2 & Mitochondrial function & MS, IFD & 3 families & $\begin{array}{l}\text { Birth to } \\
\text { Infancy }\end{array}$ & $\begin{array}{l}\text { Pure or with lower limb amyotrophy, } \\
\text { developmental delay, cerebellar } \\
\text { atrophy, seizures }\end{array}$ \\
\hline $\begin{array}{l}\text { SPG78 } \\
(617225)\end{array}$ & $1 p 36.13$ & ATP13A2 & $\begin{array}{l}\text { Autophagy, membrane } \\
\text { trafficking, mitochondrial } \\
\text { function }\end{array}$ & MS, NS, IFD & 5 families & Adulthood & $\begin{array}{l}\text { Cognitive impairment, parkinsonism, } \\
\text { ataxia, dysarthria, cerebellar and } \\
\text { cortical atrophy, axonal sensorimotor } \\
\text { peripheral neuropathy }\end{array}$ \\
\hline
\end{tabular}




\begin{tabular}{|c|c|c|c|c|c|c|c|}
\hline $\begin{array}{l}\text { SPG79 } \\
(615491)\end{array}$ & $4 p 13$ & UCHL1 & DNA damage response & MS & 2 families & Childhood & $\begin{array}{l}\text { Optic atrophy, nystagmus, cerebellar } \\
\text { ataxia, axonal sensorimotor } \\
\text { neuropathy }\end{array}$ \\
\hline $\begin{array}{l}\text { SPOAN } \\
(609541)\end{array}$ & $11 q 13,2$ & KLC2 & Motor protein (axonal transport) & RG & $\begin{array}{l}47 \text { sibships, } \\
\text { endemic to } \\
\text { Brazil }\end{array}$ & Infancy & $\begin{array}{l}\text { Congenital optic atrophy, dysarthria, } \\
\text { neuropathy, acoustic startle }\end{array}$ \\
\hline \multicolumn{8}{|c|}{ X-linked forms } \\
\hline $\begin{array}{l}\text { SPG1 } \\
(303350)\end{array}$ & Xq28 & L1CAM & $\begin{array}{l}\text { Cell adhesion, neurite } \\
\text { outgrowth, myelination }\end{array}$ & $\begin{array}{l}\text { MS, NS, FR, } \\
\text { RG, SPL }\end{array}$ & $\begin{array}{l}\text { Rare with } \\
\text { spasticity }\end{array}$ & Infancy & $\begin{array}{l}\text { TCC, cognitive impairment, adducted } \\
\text { thumbs, hydrocephalus }\end{array}$ \\
\hline $\begin{array}{l}\text { SPG2 } \\
(312920)\end{array}$ & Xq22.2 & $\begin{array}{l}\text { PLP1 } \\
\text { (proteolipid } \\
\text { protein 1) }\end{array}$ & Primary constituent of myelin & $\begin{array}{l}\text { MS, NS, FR, } \\
\text { RG, SPL }\end{array}$ & $\begin{array}{l}\text { Rare with } \\
\text { spasticity }\end{array}$ & $\begin{array}{l}\text { Infancy to } \\
\text { childhood }\end{array}$ & $\begin{array}{l}\text { Congenital nystagmus, cognitive } \\
\text { impairment, ataxia, seizures, allelic to } \\
\text { Pelizaeus-Merzbacher }\end{array}$ \\
\hline $\begin{array}{l}\text { SPG16 } \\
(300266)\end{array}$ & $\mathrm{Xq11.2}$ & Unknown & - & - & 2 families & Infancy & $\begin{array}{l}\text { Pure or with mild cognitive } \\
\text { impairment, motor aphasia, vision loss }\end{array}$ \\
\hline $\begin{array}{l}\text { SPG22 } \\
(300523)\end{array}$ & $X q 13.2$ & SLC16A2 & Thyroid hormone transporter & $\begin{array}{l}\text { MS, NS, FR, } \\
\text { RG, SPL, } \\
\text { IFD }\end{array}$ & $\begin{array}{l}\text { Rare in } \\
\text { HSP } \\
\text { cohorts }\end{array}$ & Congenital & $\begin{array}{l}\text { Allan-Herndon-Dudley syndrome: } \\
\text { cognitive impairment, spastic } \\
\text { quadriplegia, hypotonia, dystonia, } \\
\text { ataxia, leukodystrophy }\end{array}$ \\
\hline $\begin{array}{l}\text { SPG34 } \\
(300750)\end{array}$ & Xq24-q25 & Unknown & - & - & 1 family & $12-25$ & Pure \\
\hline \multicolumn{8}{|c|}{ Autosomal dominant and recessive forms } \\
\hline $\begin{array}{l}\text { SPG3A } \\
(182600)\end{array}$ & $14 q 22.1$ & $\begin{array}{l}\text { ATL1(atlastin- } \\
\text { 1) }\end{array}$ & $\begin{array}{l}\text { GTPase, ER-to-Golgi transfer, } \\
\text { spastin partner, BMP signaling }\end{array}$ & $\begin{array}{l}\text { MS, NS, FR, } \\
\text { SPL, IFD, } \\
\text { RG }\end{array}$ & $\begin{array}{l}10 \% \text { ( } 39 \% \\
\text { of young } \\
\text { patients) - } \\
\text { AD form; } 1 \\
\text { family } \\
\text { reported - } \\
\text { AR form }\end{array}$ & $\begin{array}{l}\text { Mostly early } \\
\text { onset }(<10)\end{array}$ & $\begin{array}{l}\text { Pure but sometimes neuropathy, with } \\
\text { incomplete penetrance }\end{array}$ \\
\hline $\begin{array}{l}\text { SPG7 } \\
(607259)\end{array}$ & $16 q 24.3$ & $\begin{array}{l}\text { SPG7 } \\
\text { (paraplegin) }\end{array}$ & Mitochondrial ATPase & $\begin{array}{l}\text { MS, NS, FR, } \\
\text { SPL, IFD, } \\
\text { RG }\end{array}$ & $\begin{array}{l}7 \% \text { of } A R \\
\text { families }\end{array}$ & $11-42$ & $\begin{array}{l}\text { Pure or with neuropathy, optic atrophy } \\
\text { and cerebellar atrophy, ataxic gait, } \\
\text { pyramidal signs }\end{array}$ \\
\hline $\begin{array}{l}\text { SPG9 } \\
(601162 / \\
616586)\end{array}$ & $10 \mathrm{q} 24.1$ & $A L D H 18 A 1$ & P5CS pathway & MS & $\begin{array}{l}7 \mathrm{AD} \\
\text { families, } 2 \\
\text { AR families }\end{array}$ & $\begin{array}{l}13-59(A D) \\
1-7(A R)\end{array}$ & $\begin{array}{l}\text { Pure or with cataracts, skeletal } \\
\text { abnormalities, gastroesophageal } \\
\text { reflux, amyotrophy, intellectual } \\
\text { disability }\end{array}$ \\
\hline
\end{tabular}




\begin{tabular}{|c|c|c|c|c|c|c|c|}
\hline $\begin{array}{l}\text { SPG18 } \\
(611225) \\
\& \\
\text { SPG37 } \\
(611945)\end{array}$ & $8 p 11.2$ & ERLIN2 & $\begin{array}{l}\text { ER-associated degradation } \\
\text { (ERAD) pathway, lipid } \\
\text { metabolism }\end{array}$ & $\begin{array}{l}\text { MS, SPL, } \\
\text { RG }\end{array}$ & $\begin{array}{l}5 \text { AR } \\
\text { families; } 2 \\
\text { AD families }\end{array}$ & $1-19$ & $\begin{array}{l}\text { AR: complex with contractures, } \\
\text { cognitive impairment and sometimes } \\
\text { seizures; AD: pure form }\end{array}$ \\
\hline $\begin{array}{l}\text { SPG30 } \\
(610357)\end{array}$ & $2 q 37.3$ & KIF1A & Motor protein (axonal transport) & MS, FR & Rare & $1-30$ & $\begin{array}{l}\text { AR:pure or with neuropathy, } \\
\text { cerebellar signs, ataxia, cognitive } \\
\text { impairment; AD: complex with } \\
\text { cerebellar atrophy, TCC, motor and } \\
\text { intellectual retardation }\end{array}$ \\
\hline $\begin{array}{l}\text { SPG72 } \\
(615625)\end{array}$ & $5 q 31.2$ & REEP2 & ER morphogenesis & MS, SPL & $\begin{array}{l}2 \text { families - } \\
\text { AD, } \quad 2 \\
\text { families - } \\
\text { AR }\end{array}$ & $\begin{array}{l}\text { Infancy to } \\
\text { childhood }\end{array}$ & $\begin{array}{l}\text { Pure or with amyotrophy, mild } \\
\text { dysarthria }\end{array}$ \\
\hline
\end{tabular}

